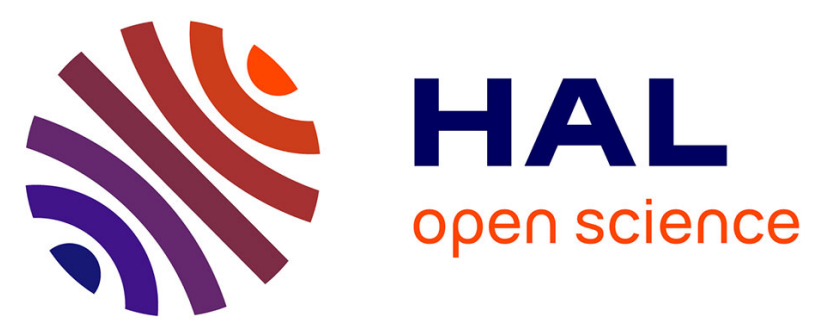

\title{
An Elegy to Rangaeris, Including a Description of Two New Genera in the Cyrtorchis-Tridactyle Clade (Orchidaceae, Angraecinae)
}

João Farminhão, Tania d'Haijère, Vincent Droissart, Landry Dumbo Isonga, Ling Dong, Simon Verlynde, Gregory Plunkett, Murielle Simo-Droissart, Tariq Stévart

\section{To cite this version:}

João Farminhão, Tania d'Haijère, Vincent Droissart, Landry Dumbo Isonga, Ling Dong, et al.. An Elegy to Rangaeris, Including a Description of Two New Genera in the Cyrtorchis-Tridactyle Clade (Orchidaceae, Angraecinae). Annals of the Missouri Botanical Garden, 2020, 105 (3), pp.300-322. 10.3417/2020472 . hal-02951857

\section{HAL Id: hal-02951857 https://hal.inrae.fr/hal-02951857}

Submitted on 23 Nov 2021

HAL is a multi-disciplinary open access archive for the deposit and dissemination of scientific research documents, whether they are published or not. The documents may come from teaching and research institutions in France or abroad, or from public or private research centers.
L'archive ouverte pluridisciplinaire HAL, est destinée au dépôt et à la diffusion de documents scientifiques de niveau recherche, publiés ou non, émanant des établissements d'enseignement et de recherche français ou étrangers, des laboratoires publics ou privés. 


AN ELEGY TO RANGAERIS,
INCLUDING A DESCRIPTION OF
TWO NEW GENERA IN THE
CYRTORCHIS-TRIDACTYLE
CLADE (ORCHIDACEAE,
ANGRAECINAE)

João N. M. Farminhão, ${ }^{2,3 \dagger *}$ Tania D'haijère, ${ }^{2,4 \dagger}$ Vincent Droissart, ${ }^{2,5,6,7}$ Landry Dumbo Isonga, ${ }^{8}$ Ling Dong, ${ }^{9}$ Simon Verlynde, ${ }^{9,10}$ Gregory M. Plunkett, ${ }^{9}$ Murielle Simo-Droissart, ${ }^{7}$ and Tariq Stévart ${ }^{2,5,11}$

\begin{abstract}
The phylogenetic position of Rangaeris (Schltr.) Summerh. has been one of the most problematic issues of angraecoid orchid taxonomy. A recently published phylogenetic tree with nearly comprehensive taxon sampling of African angraecoid orchids suggested that this genus was polyphyletic, as its species appear nested within different subclades of the Cyrtorchis-Tridactyle clade. However, the lack of DNA data for the generic type, R. muscicola (Rchb. f.) Summerh., and for the little-known species $R$. longicaudata (Rolfe) Summerh. and $R$. trilobata Summerh., has precluded an integrative reappraisal of the delimitation of this genus. Here we present the results of a new phylogenetic analysis of one nuclear (ITS) and five plastid markers (matK, rps 16, trnC-pet $N$ intergenic spacer, trnL-trnF intergenic spacer, ycfl) for all six species of Rangaeris, including those recently transferred to Podangis Schltr. and Ypsilopus Summerh., together with a representative sampling of 14 other species of the genera Cyrtorchis Schltr., Listrostachys Rchb. f., Plectrelminthus Raf., Summerhayesia P. J. Cribb, Tridactyle Schltr., and Ypsilopus. Based on molecular and morphological evidence, R. muscicola is transferred to Podangis, where Rangaeris is reduced to the rank of section. In addition, $R$. longicaudata and R. trilobata are each moved to new monotypic genera, Planetangis Stévart \& Farminhão and Aziza Farminhão \& D'haijère, respectively. An identification key for all genera of the Cyrtorchis-Tridactyle clade is presented, together with one for the three species of recircumscribed Podangis. Finally, taxonomic accounts of the new genera are presented, including amended descriptions, illustrations, distribution maps, and preliminary conservation status assessments of their species.
\end{abstract}

Key words: Africa, Angola, Aziza, Democratic Republic of the Congo, Epidendroideae, IUCN Red List, lectotypification, new combinations, Planetangis, Podangis, Vandeae, Welwitsch.

${ }^{1}$ We thank the curators and staff of BM, BR, BRLU, COI, K, LIBR, LISU, MO, P, W, WAG, and YA for making their collections available and for kindly allowing the authors to use the facilities of their institutions. Lab work and herbarium visits were supported by the U.S. National Science Foundation (1051547, T. Stévart as principal investigator [PI], G. M. Plunkett as Co-PI) and by the Belgian Fund for Scientific Research (F.R.S.-FNRS). Ongoing Ph.D. research carried out by the first two authors is funded by the Belgian Fund for Research Training in Industry and Agriculture (FRIA) of the F.R.S.-FNRS (scholarships F 3/5/5 - FRIA/FC 33848881 to J. N. M. F. and 33848291 to T. D.). We are grateful to the American Orchid Society for supporting the work of M. S.-D., V. D., and T. S. in Central Africa. The authors are grateful to the authorities of the Higher Teachers' Training College, University of Yaoundé I, for hosting the Yaoundé shade house. We express our sincere gratitude to Professor Bonaventure Sonké for the supervision of this living collection in Cameroon, and to Laura Azandi, Catherina Guiakam, Gyslène Kamdem, and Sandrine Mayogo for collecting leaf samples in the Yaoundé shade house for DNA extraction. We are grateful to Eric Akouangou, Bakita Bakita, and Christelle Nyangala for collecting specimens in the Sibang shade house (Libreville, Gabon). We are thankful to JeanPhilippe Biteau from Jardi-Gab (Libreville), whose living collection of orchids was of great importance for describing the new genus Planetangis. We thank Vincent Deblauwe for sharing photographs of specimens of Aziza and Planetangis housed at FHI. Fieldwork in Gabon was undertaken under the memorandum of understanding between the Centre National de la Recherche Scientifique et Technologique (CENAREST) and the Missouri Botanical Garden (MBG), permit AR0011/17. We thank the director of Institut de Pharmacopée et de Médecine Traditionelle (IPHAMETRA), Henri Paul Bourobou Bourobou, and the curator of the Herbier National du Gabon, Nestor Engone Obiang, for supporting our research. Fieldwork that led to the discovery of $P$. longicaudata in Guinea was conducted during the Baseline Study of an Environmental Impact Assessment conducted for the Nimba project of the Société des Mines de Fer de Guinée (SMFG). T. S. would like to thank the staff of SMFG for their help and assistance in the field. Fieldwork that allowed the collection of fresh tissue samples of Aziza trilobata in Gabon and São Tomé was financed by a grant from the King Leopold III Fund for Nature Conservation and Exploration awarded to T. D. and mobility grants from FNRS awarded to T. D. and J. N. M. F. We are thankful to Arlindo de Carvalho (Direção Geral do Ambiente), Aurélio Rita (Direção do Parque Natural de Obô), and the staff of Bom Sucesso Botanic Garden for their logistical support in São Tomé. For their assistance during fieldwork in São Tomé, J. N. M. F. and T. D. would like to thank Estêvão Soares, Dulai Samba, Tomé de Almeida, Gil Alamô, and Super Alberto. We thank Sara Albuquerque from the University of Évora for helping us locate the correspondence between Friedrich Welwitsch and Heinrich Gustav Reichenbach at the Natural History Museum Library and Archives, and Laura Trosser for making the scans of the respective letters available to us. We are grateful to Christian Bräuchler from W for translating from the German the aforementioned letters related to Welwitsch's Angolan orchid collections. We thank Gyslène Kamdem and Ehoarn Bidault for sharing their photographs of Podangis, and Laura Azandi and Maël Dewynter/Fondation Biotope pour la biodiversité for making available their photographs of Cyrtorchis and Aziza, respectively. Finally, Laura Azandi is also acknowledged for her invaluable insights into the morphology of the genus Cyrtorchis.

(Footnotes continue on next page.) 
Over the past two decades, a significant effort has been made to clarify relationships in the large Orchidaceae, including phylogenetic studies based on molecular data (Chase et al., 2015; Freudenstein \& Chase, 2015). Within the largest subfamily, Epidendroideae, and more specifically within the tribe Vandeae, several recent studies have focused on the systematics of subtribe Angraecinae in Madagascar and the Mascarene Islands (see Carlsward et al., 2006; Micheneau et al., 2008; Andriananjamanantsoa et al., 2016), in the Neotropics (Carlsward et al., 2003; Pessoa et al., 2018), and in tropical Africa (SimoDroissart et al., 2018a). Based on the results of SimoDroissart et al. (2018a), five papers were recently published that together have reassessed the taxonomy of most African angraecoid genera (Descourvières et al., 2018; Farminhão et al., 2018; Simo-Droissart et al., 2018b, 2018c; D’haijère et al., 2019), although some groups remain to be treated. Among these, the genus Rangaeris (Schltr.) Summerh. continues to be one of the key unresolved issues in this large angraecoid radiation (Carlsward, 2014; Cribb, 2014a; Simo-Droissart et al., 2018a). Rangaeris was first coined by Schlechter (1918: 121) for a section of Aerangis Rchb.f. (of which it is an anagram) to accommodate nine "species" characterized by two separate stipes and one or two viscidia. Summerhayes (1936a, 1936b), adhering to Schlechter's (1918) morphological definition, raised Rangaeris to the rank of genus and recognized seven species, including $R$. trilobata Summerh as a novelty. However, Summerhayes clearly had doubts about its delimitation, stating: "Rangaeris is a rather heterogeneous assemblage composed of several groups of closely allied species. Whether it will be possible to maintain it when further discoveries, which are inevitable, are made and further investigations have been carried out, is open to question" (Summerhayes, 1936b: 227-228).

Indeed, several recent molecular studies have now shown that Rangaeris is polyphyletic and that species historically assigned to the genus are nested in Angraecum Bory, Diaphananthe Schltr., Rhipidoglossum Schltr., and mostly in a clade including Cyrtorchis Schltr.,
Listrostachys Rchb. f., Podangis Schltr., Plectrelminthus Raf., Tridactyle Schltr., and Ypsilopus Summerh. (Carlsward et al., 2006; Simo-Droissart et al., 2018a; D'haijère et al., 2019). Based on both molecular and morphological evidence, the process of dismantling Rangaeris has recently started, with one species being moved to Podangis (Cribb \& Carlsward, 2012) and two species to Ypsilopus (D'haijère et al., 2019). This taxonomic exodus from Rangaeris to closely allied genera highlights the need for an exhaustive reassessment of the phylogenetic position of R. muscicola, the generic type, and the two other currently recognized species that remain in the genus (i.e., R. longicaudata (Rolfe) Summerh. and R. trilobata Summerh.) in the broader context of a reappraisal of generic delimitations in the Cyrtorchis-Tridactyle clade. Rangaeris longicaudata is a little-known species from tropical West and Central Africa whose morphology and ecology were first described in some detail by Pérez-Vera (2003). Rangaeris trilobata, another poorly known species confined to Central Africa (Droissart et al., 2009), exhibits a distinctive scandent habit, which led Rice (2006) to transfer it to Solenangis Schltr., together with Dinklageella Mansf. (see Rice, 2006), a taxonomic decision that was, however, not accepted by Cribb (2014a) based on several morphological traits. Thus, the positions of $R$. longicaudata and R. trilobata remained unclear, mainly because of a lack of adequate material for molecular phylogenetic analysis. Indeed, of all former members of Rangaeris, only R. longicaudata and R. trilobata had never been included or discussed in any phylogenetic analysis, which precluded understanding the position of Rangaeris within angraecoids, and in turn made it impossible to adequately recircumscribe the genus. However, recent fieldwork in Gabon and São Tomé and Príncipe, as well as sampling of the orchid collection from Jardi-Gab in Libreville, Gabon, has provided the opportunity to obtain DNA sequence data for these two taxonomically puzzling species.

Here we have produced new sequences from six markers (ITS, matK, rps16, trnC-pet $N$ intergenic spacer, trnL-trnF

2 Herbarium et Bibliothèque de Botanique africaine, Université Libre de Bruxelles, campus de la Plaine, boulevard du Triomphe, CP 265, B-1050, Brussels, Belgium.

3 Plant Ecology and Biogeochemistry, Université Libre de Bruxelles, campus de la Plaine, boulevard du Triomphe, CP 244, B1050, Brussels, Belgium.

${ }^{4}$ Evolutionary Biology and Ecology, Faculté des Sciences, C.P. 160/12, Université Libre de Bruxelles, 50 Avenue F. Roosevelt, BE-1050 Brussels, Belgium.

5 Missouri Botanical Garden, Africa \& Madagascar Department, 4344 Shaw Blvd., St. Louis, Missouri 63110, U.S.A.

6 AMAP Lab, IRD, CIRAD, CNRS, INRAE, University of Montpellier, Montpellier, France.

7 Plant Systematics and Ecology Laboratory, Higher Teachers' Training College, University of Yaoundé I, P.O. Box 047, Yaoundé, Cameroon.

8 Département de l'environnement, Faculté de sciences, Université du Cinquantenaire de Lwiro, Lwiro, Sud Kivu, Democratic Republic of the Congo.

9 Cullman Program for Molecular Systematics, New York Botanical Garden, The Bronx, New York 10458-5126, U.S.A.

10 Ph.D. Program in Biology, Graduate Center, City University of New York, 365 5th Ave., New York, New York 10016, U.S.A.

11 Meise Botanic Garden, Domein van Bouchout, Nieuwelaan 38, B-1860 Meise, Belgium.

* Author for correspondence: jnunesde@ulb.ac.be

$\dagger$ These authors contributed equally to this work. 
intergenic spacer, $y c f 1$ ), expanding the dataset of SimoDroissart et al. (2018a), who used three markers to examine phylogenetic relationships across all major lineages of African angraecoids, with the notable exception of two key Rangaeris species (viz. R. muscicola and R. trilobata). Given the new availability of samples from these species, we have investigated the phylogenetic relationships within Rangaeris, which could not be unraveled by SimoDroissart (2018a). We have followed an approach combining maximum likelihood and Bayesian analyses that has proved useful for exploring relationships among angraecoids in other recent studies (Martos et al., 2017; D'haijère et al., 2019). The goal of this study is to assess the monophyly of Rangaeris by clarifying the phylogenetic position of $R$. longicaudata and $R$. trilobata relative to the generic type, $R$. muscicola, and of the genus relative to the other genera in the larger clade that includes Cyrtorchis and Tridactyle, using both molecular phylogenetic analyses and complementary morphological observations. We also provide an identification key to the genera included in the Cyrtorchis-Tridactyle clade, along with a key to species belonging to a redefined genus Podangis and amended detailed descriptions, distribution maps, and conservation status of $R$. longicaudata and R. trilobata.

\section{Materials and Methods}

\section{TAXON SAMPLING FOR MOLECULAR ANALYSES}

Thirty-nine samples representing 25 species in the following 12 genera were sampled: Aerangis, Cyrtorchis, Listrostachys, Mystacidium Lindl., Nephrangis (Schltr.) Summerh., Podangis, Plectrelminthus, Rangaeris, Solenangis, Summerhayesia P. J. Cribb, Tridactyle, and Ypsilopus (Appendix 1). Specimens of Eggelingia Summerh., currently regarded as synonymous with Tridactyle (see Rice, 2005; Simo-Droissart et al., 2018a), were also included. All currently recognized species of Rangaeris were sampled. To explore the position of Rangaeris in the clade containing Cyrtorchis and Tridactyle, we also included representatives from all the genera of this clade. The outgroup comprised four accessions from Aerangis, Mystacidium, Nephrangis, and Solenangis, which were selected based on the topologies obtained by Carlsward et al. (2006) and Simo-Droissart et al. (2018a). Leaf tissue samples were obtained from São Tomé and Príncipe, Cameroon, and Gabon. Plants from Cameroon and Gabon were grown in shade houses monitored by our teams in Yaoundé (for those collected in Cameroon), Libreville (Sibang and Jardi-Gab collection), and Tchimbélé (see Stévart et al., 2020). Plants cultivated in the shade houses yielded high-quality flowering specimens that ensure accuracy in species identification of the leaf material used for DNA extraction.

The 63 newly obtained sequences were combined with 71 previously published sequences (Carlsward et al.,
2006; Simo-Droissart et al., 2018a; D’haijère et al., 2019) retrieved from GenBank (<https://www.ncbi.nlm.nih.gov/ genbank/ $>$ ). Voucher specimens and respective metadata are provided in Appendix 1.

\section{DNA EXTRACTION, AMPLIFICATION, AND SEQQUENCING}

Genomic DNA was extracted from silica gel-dried leaf material and herbarium specimens using a modified version of the Doyle and Doyle (1987) protocol (using $1 \mathrm{~g}$ of fresh leaf tissue or $0.2-0.3 \mathrm{~g}$ of dried material) or the NucleoSpin plant kit protocol from Macherey-Nagel (Düren, Germany), according to the manufacturer's instructions. The following primers were used for PCR amplification and sequencing of the six DNA regions: (1) primers ITS-A and ITS-C for ITS (Blattner, 1999); (2) primers trnL (UAA) 3 ' exon and trnF (GAA) gene for the $t r n L-F$ intergenic spacer (Taberlet et al., 1991); (3) primers 19F (Molvray et al., 2000), 1326R (Cuénoud et al., 2002), 390F (Cuénoud et al., 2002), and trnK-2R (Johnson \& Soltis, 1994) for matK; (4) primers rps16-1F and rps16$2 \mathrm{R}$ for the rps16 intron (Oxelman et al., 1997); (5) primers trnC and petN-1R for the trnC-pet $N$ intergenic spacer (Lee \& Wen, 2004); and (6) primers 3720F, IntR, IntF, and 5500R (Neubig et al., 2009) for $y c f 1$. One of three thermocyclers (Biometra TProfessional thermocycler, PTC-100 or PTC200, Bio-Rad Laboratories, Inc., Hercules, California, U.S.A.) was used for PCR amplification. The reaction mixtures for all markers included $0.125 \mu \mathrm{L}(5 \mathrm{U} / \mu \mathrm{L})$ of Taq polymerase (Qiagen, Valencia, California, U.S.A.), $0.25 \mu \mathrm{L}$ of each primer $(10 \mu \mathrm{M}), 1-2 \mu \mathrm{L}$ of template genomic DNA extract (of unquantified concentration), $2.5 \mu \mathrm{L}$ PCR buffer, $1 \mu \mathrm{L} \mathrm{MgCl} 2(25 \mathrm{mM}), 0.5 \mu \mathrm{L}$ dNTPs $(10 \mu \mathrm{M})$, and ultrapure $\mathrm{H}_{2} \mathrm{O}$ to a final volume to $25 \mu \mathrm{L}$. The amplification program included an initial denaturation at $94^{\circ} \mathrm{C}(3 \mathrm{~min}$.), 30 cycles of denaturation at $94^{\circ} \mathrm{C}(30 \mathrm{sec}$.), annealing at $50^{\circ} \mathrm{C}(y c f 1)$ or $52^{\circ} \mathrm{C}$ (all others) $\left(30 \mathrm{sec}\right.$.), elongation at $72^{\circ} \mathrm{C}$ (1 min. $30 \mathrm{sec}$. for $\mathrm{mat} K$ and $y c f 1,1 \mathrm{~min}$. for all others), and a final elongation step at $72^{\circ} \mathrm{C}$ for $10 \mathrm{~min}$.

The ExoSAP (Qiagen) enzyme mixture was used to purify the amplified products, and the BigDye Terminator v. 3.1 Cycle Sequencing Kit (Applied Biosystems, Inc., ABI, Lennik, the Netherlands) was used in cyclesequencing reactions of both complementary strands, using one of two primers used in PCR amplifications. The reaction mixture contained $1.5 \mu \mathrm{L}$ of sequencing buffer, $1 \mu \mathrm{L}$ of BigDye terminator, $0.2 \mu \mathrm{L}$ of $10 \mu \mathrm{M}$ primer, $1-3 \mu \mathrm{L}$ of unquantified amplified product, and 4.3-6.3 $\mu \mathrm{L}$ of $\mathrm{H}_{2} \mathrm{O}$, for a total reaction volume of $10 \mu \mathrm{L}$. More detailed information on cycle sequencing conditions is provided in Simo-Droissart et al. (2018a).

\section{PHYLOGENETIC ANALYSES}

Automatic base calling was inspected manually by examining electropherograms in Geneious version 9.0.5 
(Drummond et al., 2012). Sequences were aligned in MUSCLE (Edgar, 2004) as implemented in Geneious, and then manually adjusted using the same software. Phylogenetic analyses were conducted on three datasets: ITS alone, the concatenated plastid loci of the five plastid markers ( $m a t K$, rps16, trnC-pet $N$ intergenic spacer, trnL-trnF intergenic spacer, $y c f 1$ ), and a combined dataset of all nuclear and plastid sequences. We analyzed the data using two approaches, maximum likelihood (ML) and Bayesian inference (BI), to estimate phylogenetic relationships among the different genera. To select the best evolutionary model for each marker, we used PartitionFinder (2.1.1) (Lanfear et al., 2016), and a gamma distribution was used to model site heterogeneity. The ML analyses were run with RAxMLHPC2 on XSEDE (8.2.12) (Stamatakis, 2014) through the CIPRES Science Gateway (Miller et al., 2010). The support was analyzed using a bootstrap procedure that allowed RAxML to halt the bootstrapping automatically when the required criteria are met, instead of specifying the number of bootstraps for the analysis. Bootstrap support (BS) values that we considered were poor $(<50 \%)$, weak $(50 \%-70 \%)$, moderate $(>70 \%-85 \%)$, or strong $(>85 \%)$, following Kress et al. (2002). The model available in CIPRES that was closest to those recommended by PartitionFinder was GTR $+\Gamma$ for all markers in the three matrices. The specific criteria are configured using subsequent entry fields. BI analyses were run using MrBayes (3.2.6 x86) (Huelsenbeck \& Ronquist, 2001; Ronquist et al., 2012) via the CIPRES Science Gateway. Posterior probabilities (PP) were considered poor $(<0.90)$, weak $(0.90$ to $<0.95)$, moderate $(0.95$ to $<0.98$ ), and strong $(\geq 0.98$ ), following Erixon et al. (2003). The models available in MrBayes that were closest to those suggested by PartitionFinder were GTR $+\Gamma$ for all markers in all matrices. Two separate Markov chain Monte Carlo (MCMC) runs were set up with a random tree and eight chains in parallel (Huelsenbeck \& Ronquist, 2001). We performed two runs in parallel of four MCMC for $20 \times 10^{6}$ $\left(30 \times 10^{6}\right.$ for the combined matrix) generations, with trees sampled every 1000 generations (Huelsenbeck \& Ronquist, 2001). Convergence between both runs was checked against the stationary distribution by examining whether the potential scale-reduction factors were close to 1 in the pstat file, the standard deviation of split frequencies fell below 0.01 in the $\log$ file, and assessing the $\mathrm{p}$ file using the program Tracer 1.7.1 (Rambaut et al., 2018). A burn-in of $25 \%$ of the sampled trees was applied to obtain the $50 \%$ majority-rule consensus trees and the clade posterior probabilities.

\section{MORPHOLOGICAL STUDY}

Morphological data were obtained through detailed examination of ca. 800 dried and alcohol-preserved specimens deposited in BM, BR, BRLU, COI, K, LBV, LISC, LISU, MO, P, W, WAG, and YA (herbarium acronyms follow Thiers, continuously updated) of (1) the genera of the Cyrtorchis-Tridactyle clade (i.e., Cyrtorchis, Listrostachys, Plectrelminthus, Podangis, Rangaeris, Summerhayesia, Tridactyle, and Ypsilopus); (2) Nephrangis (sister to Cyrtorchis-Tridactyle in the trees of SimoDroissart et al., 2018a); (3) Solenangis and Dinklageella (which vegetatively bear a great resemblance to $R$. trilobata); and (4) Aerangis and Mystacidium (both included in the outgroup in the molecular phylogenetic analyses). Additional scans of specimens housed in FHI and LD were consulted through the Global Plants database (JSTOR, 2000-2018). All type specimens of Rangaeris and Podangis were seen, as were all collections of $R$. longicaudata and R. trilobata housed in European herbaria. Details of color, phenology, habit, and habitat were derived from photographs, field notes, observations of living material, and herbarium labels. Some photos of P. dactyloceras Schltr. and R. muscicola from Cameroon, the Democratic Republic of the Congo, and Tanzania were retrieved from the World Orchid Iconography (2015-2018) of the Swiss Orchid Foundation at the Herbarium Jany Renz and the Botanical Institute of the University of Basel; from Senckenberg's West African Plants (Brunken et al., 2008); and from Orchidaceae of Central Africa (Droissart et al., 2018). Flowers of spirit specimens, and of dried specimens after being boiled in water and rehydrated in Copenhagen mix, were observed using a Stemi SV11 stereo microscope (Carl Zeiss AG, Oberkochen, Germany). Measurements of plants were made with an uncertainty of $0.5 \mathrm{~mm}$ using a scale ruler or graph paper. Plant descriptions were prepared following the terminology of the Systematics Association Committee for Descriptive Biological Terminology (1962a, 1962b) and Beentje (2016). Distributions for each species were derived from the material examined and compared with chorological data available from the World Checklist of Selected Plant Families (Govaerts et al., 2019). Preliminary assessments of risk of extinction were made using the IUCN Red List categories and criteria (IUCN, 2012, 2019). We imported the georeferenced specimen data into R software (R Core Team, 2019) and used the ConR package (Dauby et al., 2017; < https:// CRAN.R-project.org/package $=\mathrm{ConR}>$ ) to calculate area of occupancy (AOO) and extent of occurrence (EOO). The cell size for AOO was set at $2 \times 2 \mathrm{~km}$ as recommended by IUCN (2019). The number of "locations," as defined by IUCN (2019), was calculated considering the type of threats, such that a single "location" may encompass more than one adjacent subpopulation.

\section{Results}

MOLECULAR PHYLOGENETICS

We generated a total of 63 new sequences: 13 for ITS, five for $m a t K$, four for $t r n L-t r n F$ intergenic spacer, 12 for 
trnC-petN intergenic spacer, 14 for rps16, and 15 for $y c f 1$. All sequences were deposited in GenBank (Appendix 1). We combined them with 71 additional sequences available from GenBank (mostly produced by our team for previous studies), and from these we generated three datasets: a nuclear dataset based on ITS, a plastid dataset based on the combination of the five plastid markers ( $m a t K$, rpsl6, trnC-pet $N$ intergenic spacer, $\operatorname{trnL} L$-trnF intergenic spacer, $y c f 1$ ), and a combined nuclear and plastid dataset. The ITS dataset comprises 36 sequences (representing 24 taxa) with an aligned length of 385 characters; the plastid dataset includes 36 sequences (26 taxa) with 6174 characters (matK: 1860, rpsl6: 1010, trnC-petN intergenic spacer: 938, trnL-F intergenic spacer: 557, and $y c f 1: 1809$ characters), and the combined dataset contains 39 sequences (26 taxa) of 6559 characters. Trees inferred from the plastid and combined datasets were better resolved than the tree inferred from the ITS dataset alone.

Phylogenetic reconstructions produced with ML and BI methods resulted in congruent topologies and differed only in poorly supported nodes. Besides the four outgroups (Aerangis, Mystacidium, Nephrangis, and Solenangis), all trees resulting from both approaches resulted in the same three clades (Figs. 1-3): clade A, containing Cyrtorchis, Podangis, Rangaeris longicaudata, and R. muscicola, with a support value of $83 \%$ (BS) and 0.98 (PP) in the combined analyses (Fig. 1), $62 \%$ (BS) and 0.5 (PP) in the ITS analyses (Fig. 2), and $57 \%(\mathrm{BS})$ and $0.74(\mathrm{PP})$ in the plastid analyses (Fig. 3); clade B, containing $R$. trilobata with a support value of $100 \%$ (BS) and $1.0(\mathrm{PP})$ in all analyses; and clade C, containing Tridactyle with a support value of $100 \%$ (BS) and $1.0(\mathrm{PP})$ in the combined analyses (Fig. 1), 38\% (BS) and 0.5 (PP) in the ITS analyses (Fig. 2), and 97\% (BS) and 1.0 (PP) in the plastid analyses (Fig. 3).

Three other clades were retrieved from the plastid and combined analyses, but not from the ITS analyses: clade D, containing Summerhayesia with a support value of $100 \%(\mathrm{BS})$ and $1(\mathrm{PP})$ in both combined and plastid analyses (Figs. 1, 3); clade E, containing Ypsilopus with a support value of 69\% (BS) and $0.99(\mathrm{PP})$ in the combined analysis (Fig. 1) and of 74\% (BS) and 0.99 (PP) in the plastid analyses (Fig. 3); and clade F, containing Plectrelminthus and Listrostachys with a support value of $79 \%(\mathrm{BS})$ and $0.89(\mathrm{PP})$ in the combined analyses (Fig. 1) and of $81 \%$ (BS) and 0.94 (PP) in the plastid analyses (Fig. 3).

Within clade A, two groups are strongly supported in all analyses: subclade al containing Podangis, with a support value of $100 \%$ (BS) and 1.0 (PP) in both combined and plastid analyses (Figs. 1,3) and of 90\% (BS) and $1.0(\mathrm{PP})$ in the ITS analyses (Fig. 2); and subclade a3 containing Cyrtorchis, with a support value of $100 \%$ (BS) and $1.0(\mathrm{PP})$ in both combined and ITS analyses
(Figs. 1, 2) and 85\% (BS) and 0.90 (PP) in the plastid analyses (Fig. 3). A third subclade, a2, containing Rangaeris longicaudata, is strongly supported with a value of $100 \%$ (BS) and 1.0 (PP) in both the combined and the ITS analyses (Figs. 1, 2), but poorly supported with a value of $79 \%$ (BS) and 0.65 (PP) in the plastid analyses. Finally, subclade a2 is sister to subclade a3 (Cyrtorchis) in both the combined and plastid analyses (Figs. 1, 3), well supported with a value of 0.99 (PP) in the BI tree based on the combined data (Fig. 1) but poorly supported with a value of $0.84(\mathrm{PP})$ in the $\mathrm{BI}$ trees based on plastid data (Fig. 3). For the maximum likelihood analyses, clade a2 is poorly supported with a value of $59 \%$ (BS) in the ML trees based on plastid data (Fig. 3) and moderately supported with a value of $80 \%$ (BS) in the ML analysis of the combined dataset (Fig. 1).

The position of Rangaeris muscicola within clade A is left unresolved in the trees resulting from the analyses of all three datasets and both methods.

\section{MORPHOLOGICAL SURVEY}

Of all genera in the outgroup (viz., Aerangis, Nephrangis, Solenangis, and Mystacidium), Mystacidium presents the most divergent structure of the column, characterized by the well-developed rostellar midlobe and two separate stipes and viscidia. Aerangis is notably recognizable by the deeply concave stigmatic cavity with winged margins and a pollinarium with a single stipe and a thick viscidium. Nephrangis is unique in the arrangement of the perianth, with the lateral sepals adnate to the lip. Solenangis is distinctive because of its scandent habit and the inflorescences perpendicular to the stem.

No diagnostic synapomorphies were identified for the Cyrtorchis-Tridactyle clade (Fig. 1, clades A-F) when compared with genera in the outgroup.

Species in clade A (Fig. 1), namely Rangaeris muscicola, R. longicaudata, Podangis, and Cyrtorchis, share an undivided epichile and a suite of character states that could be inferred as ancestral in the CyrtorchisTridactyle clade (viz., pollinaria with two free stipes connected to a single saddle-shaped viscidium, lateral rostellar lobes longer than the midlobe and not adnate to it).

Despite the fact that Rangaeris muscicola and the two species of Podangis form part of a polytomy rather than a clade in the trees resulting from our phylogenetic analyses (Fig. 1, clade A), these three species share an identical gynostemium morphology (e.g., a saddleshaped viscidium and two slender stipes) and growth habit. Rangaeris muscicola, as well as P. dactyloceras and P. rhipsalisocia (Rchb. f.) P. J. Cribb \& Carlsward, can be distinguished from closely related taxa in clade $\mathrm{A}$ (viz., R. longicaudata and Cyrtorchis) based on the 


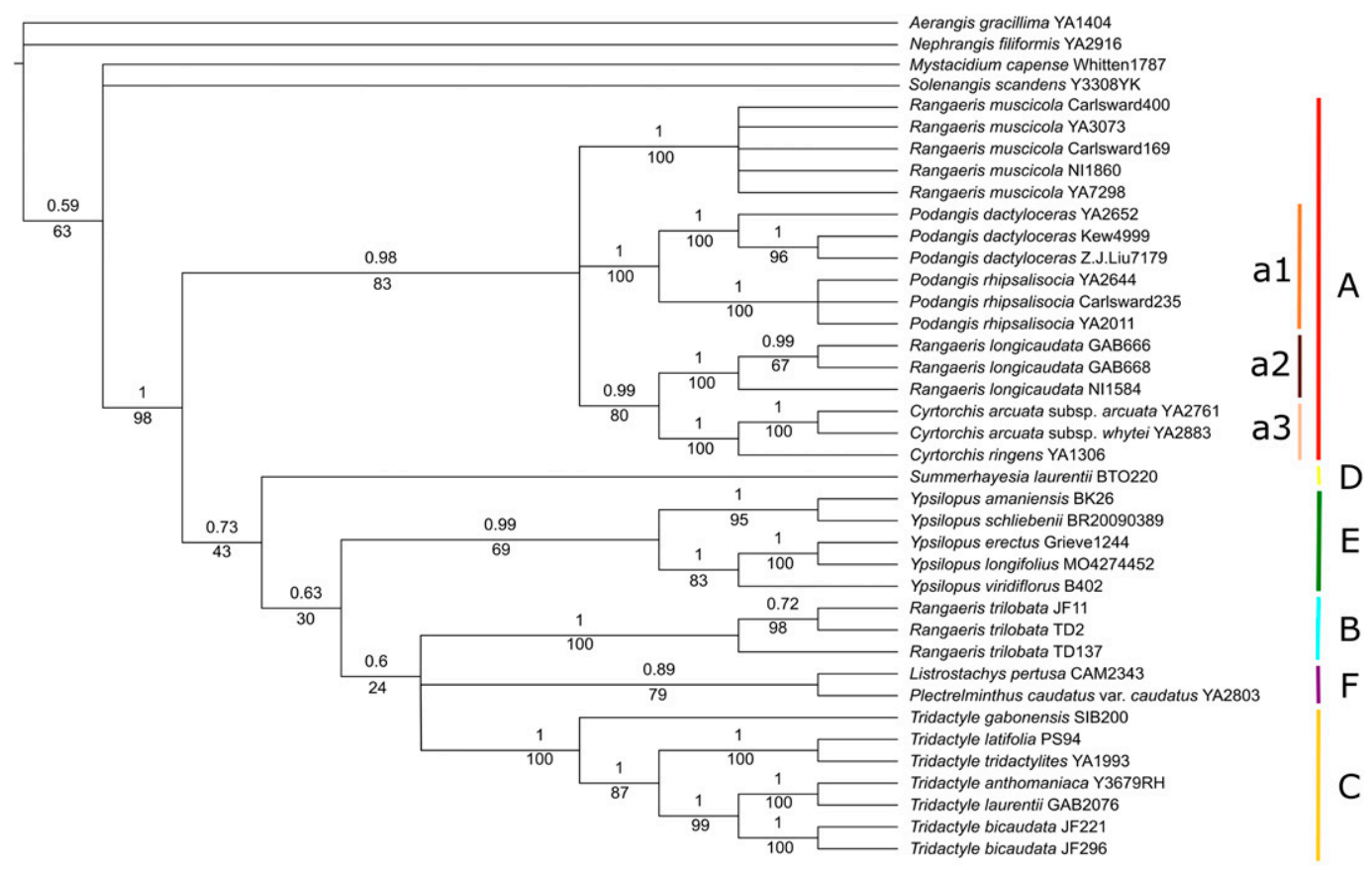

0.003

Figure 1. Phylogenetic tree of Rangaeris (Schtr.) Summerh. and allied genera, resulting from Bayesian and maximum likelihood analyses of the combined dataset, based on the combination of six markers (ITS, matK, rpsl6, trnC-pet $N$ intergenic spacer, $t r n L-F$ intergenic spacer, $y c f 1$ ) from 39 specimens representing 26 taxa using MrBayes (under the GTR $+\Gamma$ substitution model, with posterior probabilities shown above branches), and using RAxML (with the GTR $+\Gamma$ substitution model, with bootstrap percentages shown below the branches). Clade labels refer to clades discussed in the text.

presence of a lip that is dissimilar in shape to the other tepals, stipes that do not broaden markedly toward the apex, and parallel lateral rostellar lobes. All these morphological observations separate Podangis and $R$. muscicola from the remaining taxa in clade A and suggest that $R$. muscicola, and therefore the genus Rangaeris, may better be included in Podangis.

The single species in clade a2 (Rangaeris longicaudata) is sister to clade a3 (Cyrtorchis), which is corroborated by the shared presence of an "isotepaloid" perianth (i.e., the lip is identical in shape to the remaining tepals), stipes markedly broadened toward the apex, and connivent lateral rostellar lobes. However, R. longicaudata differs in several floral traits from species in clade a3 (Cyrtorchis), notably in its rounded ovary and the saddle-shaped viscidium that is about twice as long as wide. Other distinctive characters of $R$. longicaudata include the broad, beveled apex of the lateral rostellar lobes and the bilobed callus present on the lower rim of the stigma.

Species in clade a3 (Cyrtorchis) are particularly homogeneous morphologically and share distinctive floral characteristics such as the ribbed triquetrous ovary together with the forward-pointing base of the petals and sepals, the anterior expansion of the viscidium, and the very short column that touches the lip spur mouth along its lower margin.

Within clade A, the gain in grouping information associated with the inclusion of Rangaeris longicaudata in Cyrtorchis appears to be outweighed by the loss of morphological diagnosability of both taxa that would result from lumping these genera. Therefore, we argue that the recognition of $R$. longicaudata as a new monospecific genus, distinct from Cyrtorchis, best reflects the evolutionary distinctiveness of these two "isotepaloid" lineages.

Clade B contains only Rangaeris trilobata, which is both morphologically and ecologically distinctive, presenting grasping crozier-shaped root apices convergent to those of the unrelated Solenangis and Dinklageella, thus being the only scandent (i.e., climbing) species in the Cyrtorchis-Tridactyle alliance (Fig. 1, clades A-F). The truncate anterior margin of the viscidium and its deeply trilobed lip are reminiscent of genera such as Plectrelminthus and Tridactyle, setting R. trilobata apart from any other species formerly placed in Rangaeris. However, it differs from these two genera and from Listrostachys by the absence of auricles at the lip base; and from Tridactyle, Plectrelminthus, Listrostachys, and Summerhayesia in its 


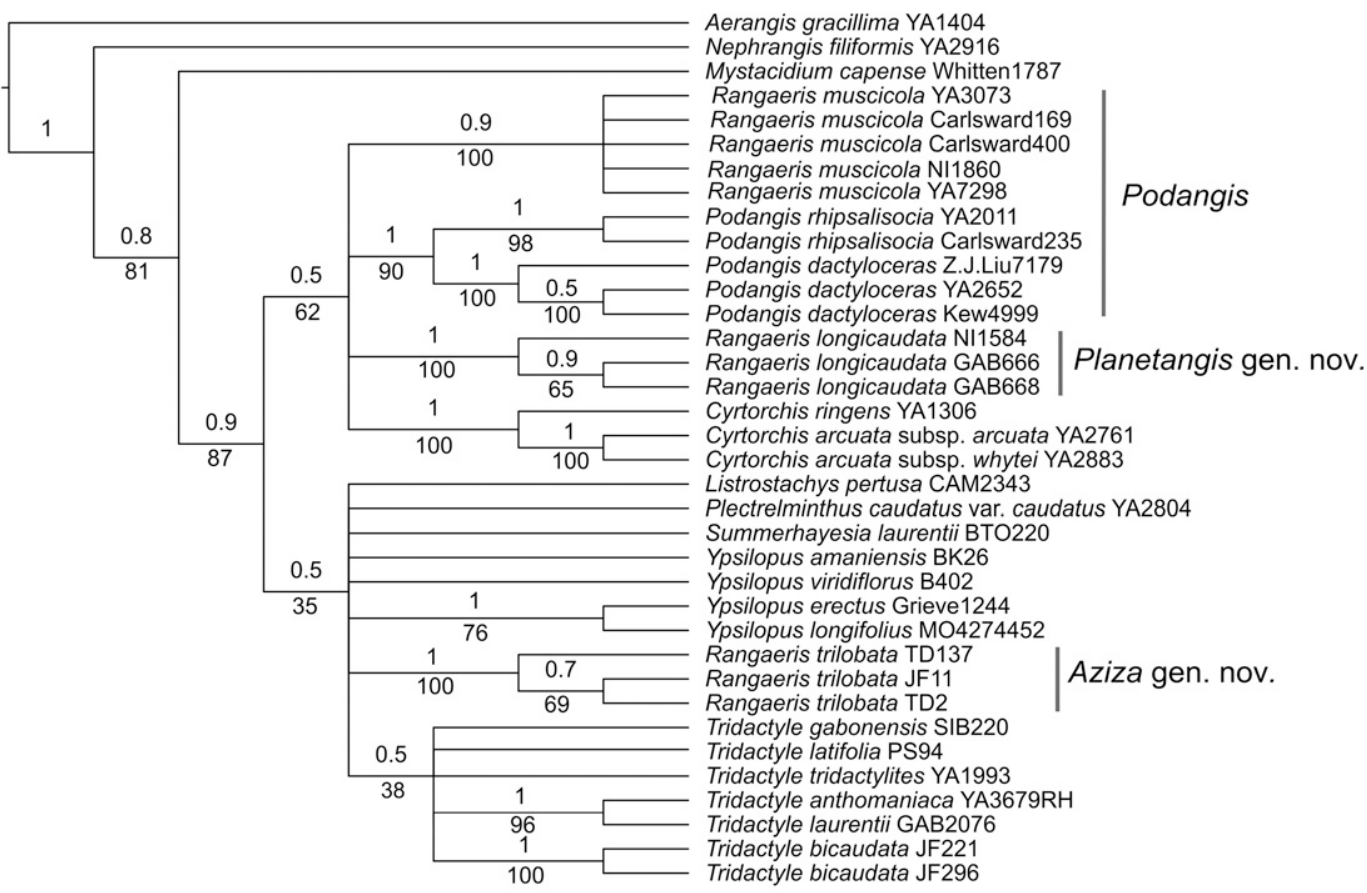

0.02

Figure 2. Phylogenetic tree of Rangaeris (Schtr.) Summerh. and allied genera, resulting from Bayesian and maximum likelihood analyses of the nuclear dataset ITS from 36 specimens representing 24 taxa using MrBayes (under the GTR $+\Gamma$ substitution model, with posterior probabilities shown above branches), and using RAxML (under the GTR $+\Gamma$ substitution model, with bootstrap percentages shown below the branches).

rostellar lobes, which are free, not fused to the midlobe along their inner margins. Rangaeris trilobata is morphologically similar to Ypsilopus in having concave stigmata with spreading margins but differs from this genus in having two separate stipes. Hence, based on the great morphological distinctiveness of $R$. trilobata, we suggest that it is better treated as a new monotypic genus.

Species in clade D (Summerhayesia) are characterized by their non-resupinate flowers and geniculate rostellum.
Our findings related to the diagnostic morphological characters of clade C (Tridactyle), clade E (Ypsilopus, including $Y$. amaniensis (Kraenzl.) D'haijère \& Stévart and Y. schliebenii (Mansf.) D'haijère \& Stévart, both formerly placed in Rangaeris) and clade F (Plectrelminthus and Listrostachys) are identical to those from D'haijère et al. (2019), who extensively analyzed and discussed the systematics of these genera.

\section{Taxonomic Treatment}

Key to Genera in Cyrtorchis-Tridactyle Aluiance, Nephrangis, and Solenangis

la. Scandent plants; roots developing clasping crozier-shaped apices.

2a. Leaves coriaceous or thin-textured, apex obtuse, subequally bilobed; inflorescences suberect, perpendicular to the stem, with peduncle shorter than rachis; column shorter than sepals and petals; anther cap apex acute; pollinaria with a single stipe; fruits ellipsoid, ca. $3 \times$ as long as wide $\ldots \ldots \ldots \ldots \ldots \ldots$ Solenangis Schltr.

2b. Leaves thin-textured, apex acute, unequally bifid; inflorescences pendent with peduncle as long as or longer than rachis; column prominent, projecting well above sepals and petals; anther cap apex truncate; pollinaria with two separate stipes; fruits narrowly ellipsoid, ca. $6 \times$ as long as wide $\ldots \ldots \ldots \ldots \ldots$ Aziza Farminhão \& D'haijère

1b. Erect, suberect or pendent plants; root apices not clasping.

3a. Stigma with concave margins; rostellar lobes free, not fused along their length.

4a. Leaves acicular; inflorescences subsessile $\ldots \ldots \ldots \ldots \ldots \ldots \ldots \ldots \ldots$ Nephangis (Schltr.) Summerh.

4b. Leaves not acicular; inflorescences markedly pedunculate. 


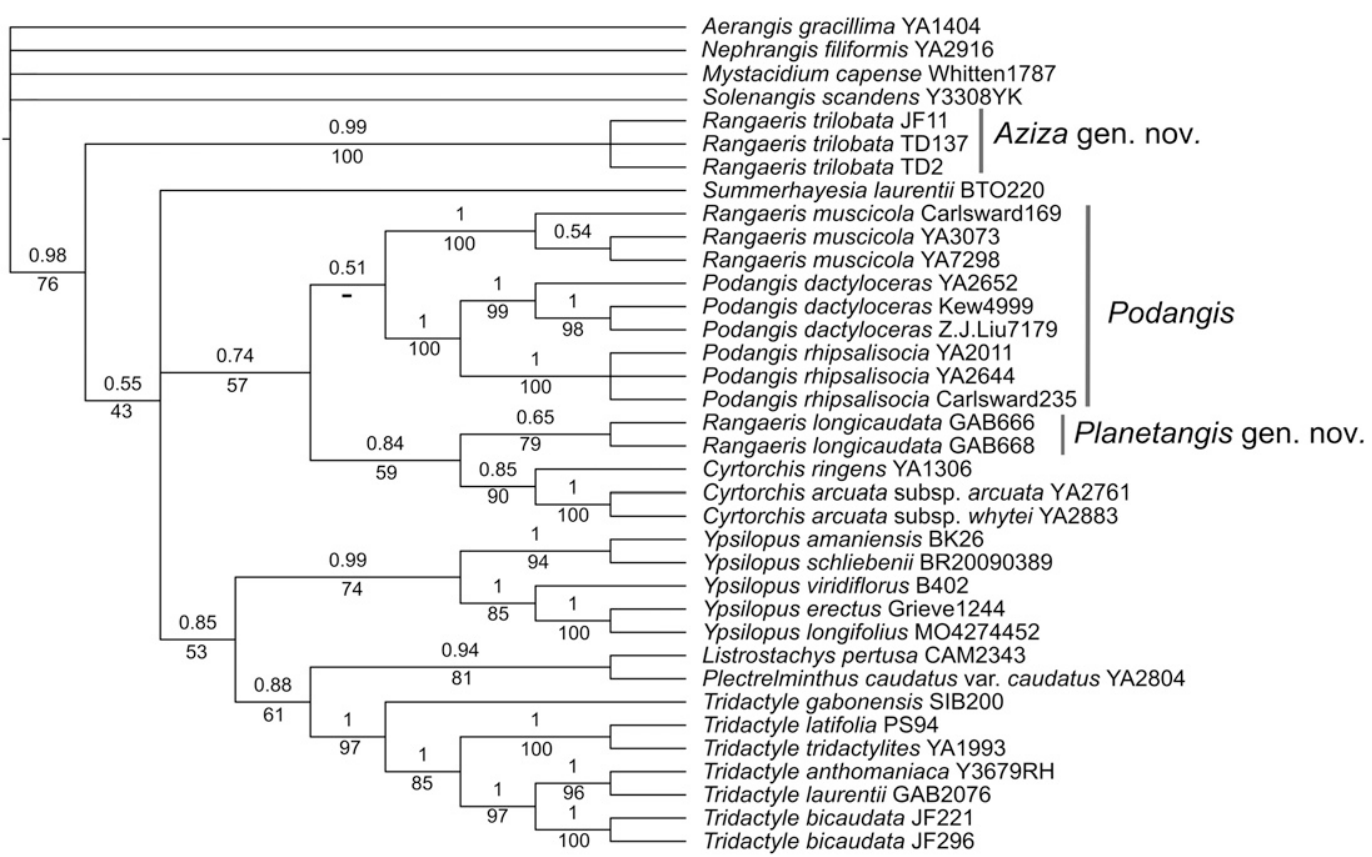

0.003

Figure 3. Phylogenetic tree of Rangaeris (Schtr.) Summerh. and allied genera, resulting from Bayesian and maximum likelihood analyses of the plastid dataset, based on the concatenation of five markers $(\mathrm{matK}, \mathrm{rps} 16$, trnC-pet $N$ intergenic spacer, $t r n L-F$ intergenic spacer, $y c f 1$ ) from 36 specimens representing 26 taxa using MrBayes (under the GTR $+\Gamma$ substitution model, with posterior probabilities shown above branches), and using RAxML (under the GTR $+\Gamma$ substitution model, with bootstrap percentages shown below branches).

5a. Pollinaria with a single Y-shaped stipe ...................... Ypsilopus Summerh.

5b. Pollinaria with two stipes, separate along their full length.

6a. Lip dissimilar to remaining tepals; stipes linear to clavate, slightly broadening toward the apex; rostellar lateral lobes parallel to each other ................... Podangis Schltr.

6b. Lip similar to remaining tepals; stipes obtriangular to obtrullate, markedly broadening toward the apex; rostellar lateral lobes connivent.

7a. Petals reflexed; column elongate, ca. $2 \times$ as long as wide, exposed; insertion point of the stipes halfway along the length of the viscidium; anterior margin of the viscidium deeply bilobed; ovary and fruits with rounded cross section ....... Planetangis Stévart \& Farminhão

7b. Petals bent forward; column very short, ca. as long as wide, concealed by the petals; insertion point of the stipes at the rear third of the length of the viscidium; anterior margin of the viscidium bifid; ovary and often the fruits triquetrous............ Cyrtorchis Schltr.

3b. Stigma relatively flat with laterally spreading to reflexed rounded wings; rostellar lobes fused along inner margins.

8a. Flowers hyper-resupinate; lip entire, concave, with no auricles at base; a single stipe; rostellum geniculate .......................................... Summerhayesia P. J. Cribb

8b. Flowers resupinate to hyper-resupinate; lip obscurely to markedly tridentate, with auricles at base; 1 or 2 stipes; rostellum not geniculate.

9a. Column foot prominent; pollinaria with 2 stipes broadening toward the apex and a horseshoe-shaped

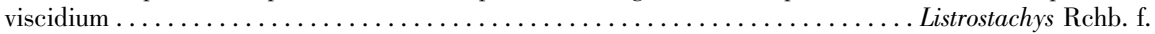

9b. Column foot absent or obscure; pollinaria with a single stipe and a viscidium circular to elliptic, rarely horseshoe-shaped.

10a. Leaves imbricate, without ligules; flowers hyper-resupinate; lip with prominent acute auricles at base, spur helically twisted, 15-25 cm long, with a raised acute tooth in mouth ... Plectrelminthus Raf.

10b. Leaves imbricate to well spaced, with or without ligules; flowers resupinate to hyper-resupinate; lip with acute to rounded auricles at base, spur not helically twisted, shorter than $15 \mathrm{~cm}$, without a

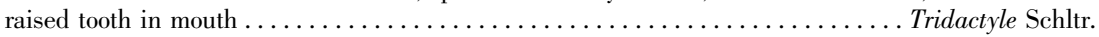




\section{PODANGIS REDEFINED}

Podangis Schltr., Beih. Bot. Centralbl. 36(2): 82. 1918. TYPE: Podangis dactyloceras (Rchb. f.) Schltr., Beih. Bot. Centralbl. 36(2): 82. 1918.

Neowolffia O. Gruss, Orchid. Atlas: 239. 2007. TYPE: Neowolffia rhipsalisocia (Rchb. f.) O. Gruss, Orchid. Atlas: 239. 2007. Basionym: Angraecum rhipsalisocium Rehb. f., Flora 48: 189. 1865.

Rangaeris (Schltr.) Summerh., Bull. Misc. Inform. Kew 1936: 227. 1936. TYPE: Rangaeris muscicola (Rchb. f.) Summerh. in J. Hutchinson \& J. M. Dalziel, Fl. W. Trop. Afr. 2: 450. 1936. Basionym: Aeranthes muscicola Rchb. f., Flora 48: 190. 1865.

Notes. The genus Rangaeris (with its type, R. muscicola) is here subsumed under Podangis based on morphological evidence, but $R$. longicaudata and $R$. trilobata are each moved to newly described monotypic genera (see below).

Podangis was monotypic for the greater part of its taxonomic history, until the recent transfer of P. rhipsalisocia from Rangaeris. The two species formed a strongly supported clade and also shared the same psygmoid habit and an identical column morphology (Cribb \& Carlsward, 2012; Cribb, 2014b). Both species also have iridiform leaves, campanulate (i.e., not fully open) flowers, obovoid pollinia, proportionally broad lateral rostellar arms, and a chromosome count of $2 n=$ 46 (Arends \& van der Laan, 1986), which distinguish them from R. muscicola, which has conduplicate leaves, stellate flowers, subglobose pollinia, very slender rostellar arms, and a chromosome count of approximately $2 n=100$ (Jones, 1967). These differences can be accommodated in the sectional treatment proposed herein, which also eliminates the need to recognize another monotypic genus, which would provide little additional grouping information for an otherwise morphologically cohesive species group. Floral autapomorphies in the three species of Podangis are probably strongly associated with three divergent pollination syndromes, with $R$. muscicola likely being sphingophilous, considering its white, jasmine-scented flowers and slender lip spur longer than $4 \mathrm{~cm}$ (see Martins \& Johnson, 2007). Similarly to Carlsward et al. (2006), we were unable to fully resolve the phylogenetic position of $R$. muscicola relative to Podangis when considering only molecular data. Future phylogenetic studies with a more comprehensive molecular dataset would be helpful in providing stronger support for a clade uniting the three species of Podangis, in agreement with our taxonomic decision to include R. muscicola within Podangis. Our redelimitation of Podangis and accompanying phylogenetic hypothesis are intended to provoke further systematic research. Phylogenomic analysis may one day reveal whether our treatment withstands the test of evidence and whether candidate synapomorphies (viz., the saddle-shaped viscidium and two slender stipes) will need to be reinterpreted as symplesiomorphic.

Key to PodangIS

la. Leaves conduplicate; flowers stellate, petals and sepals convex, bent backward; lip spur 4-12 cm; ovary and pedicel lepidote; lateral rostellar lobes ca. $4 \times$ as long as wide; pollinia subglobose . . P. muscicola (Rchb. f.) Farminhão \& D'haijère

1b. Leaves iridiform; flowers campanulate (i.e., not fully open), petals and sepals concave, bent forward; lip spur $<2 \mathrm{~cm}$; ovary and pedicel glabrous or glandular; lateral rostellar lobes ca. $2 \times$ as long as wide; pollinia obovoid.

2a. Inflorescence a secund raceme, flowers alternate; floral bracts obtuse, brownish orange; lip spur hook-shaped; anther cap whitish to cream, truncate at apex; floral pedicel and ovary green, densely glandular, covered in whitish articulate trichomes ........................ rhipsalisocia (Rchb. f.) P. J. Cribb \& Carlsward

2b. Inflorescence a condensed corymbiform raceme, flowers spirally arranged; floral bracts acute, whitish to light brown; lip spur conical, constricted in middle and inflated into two umbonate lobules at apex; anther cap green turning yellow in late anthesis, acute at apex; floral pedicel white and ovary green with whitish ribs, glabrous ...

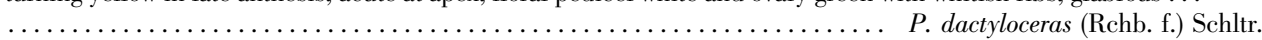

Podangis sect. Podangis.

Podangis dactyloceras (Rchb. f.) Schltr., Beih. Bot. Centralbl. 36(2): 82. 1918. Basionym: Listrostachys dactyloceras Rchb. f., Flora 48: 190. 1865. Angorchis dactyloceras (Rchb. f.) Kuntze, Revis. Gen. Pl. 2: 651. 1891. Angraecum dactyloceras (Rchb. f.) Schltr., Westafr. Kautschuk-Exped: 283. 1900. TYPE: Angola. Malanje: prope cataractum magnum fl. Cuanza et in insula Calemba [Cataratas do Condo and Ilha Calemba], 18 Mar. 1857, F. M. J. Welwitsch 677 (holotype, W image! [W-0011349], isotypes BM! [BM-000534987],
COI!, K! [K-000306626], LISU! [LISU-221680]). Figure 4G-I.

Listrostachys forcipata Kraenzl., Bot. Jahrb. Syst. 19: 254. 1894. Angraecum forcipatum (Kraenzl.) Engl. in H. G. A. Engler \& O. Drude, Veg. Erde 9(II): 420. 1908. TYPE: Cameroon. Southwest: Urwald westlich Buea, P. R. Preuss s.n. (holotype, $\mathrm{B} \dagger$ ).

Listrostachys saxicola Kraenzl., Bot. Jahrb. Syst. 48: 399. 1912. TYPE: Cameroon. Adamaoua: beim Passe Tschâpe, C. L. Ledermann 2783 (holotype, $\mathrm{B} \dagger$ ).

Notes. We have located additional isotypes of Listrostachys dactyloceras at COI and LISU, which had not been cited in previous floristic treatments. As a historical note, it is almost certain that Reichenbach derived 
the species epithet "dactyloceras" from the generic name of "Dactyloceras flabellata Welw." ined. This unpublished name for a new genus and species is found handwritten by Welwitsch himself on the duplicates housed at BM and LISU, on which the earlier alternative spelling "Dactylorchisflabellata Welw." ined. can also be read.

Podangis rhipsalisocia (Rchb. f.) P. J. Cribb \& Carlsward, Phytotaxa 71: 46. 2012. Basionym: Angraecum rhipsalisocium Rchb. f., Flora 48: 189. 1865. Angorchis rhipsalisocia (Rchb. f.) Kuntze, Revis. Gen. Pl. 2: 651. 1891. Listrostachys rhipsalisocia (Rchb. f.) Rolfe in D. Oliver \& auct. suc. (eds.), Fl. Trop. Afr. 7: 158. 1897. Aerangis rhipsalisocia (Rchb. f.) Schltr., Beih. Bot. Centralbl. 36(2): 123. 1918. Rangaeris rhipsalisocia (Rchb. f.) Summerh. in J. Hutchinson \& J. M. Dalziel, Fl. W. Trop. Afr. 2: 449. 1936. Neowolffia rhipsalisocia (Rchb. f.) O. Gruss, Orchid. Atlas: 239. 2007. TYPE: Angola. Cuanza Norte: Golungo Alto, Sobati [Sobado] de Quibombo, Mar. 1856, F. M. J. Welwitsch 662 (holotype, W image! [W-0011597]; isotypes BM! [BM000540219], K! [K-000306339], LSU! [LISU-221675]). Figure $4 \mathrm{D}-\mathrm{F}$.

Listrostachys trachypus Kraenzl., Bot. Jahrb. Syst. 19: 253. 1894. Rangaeris trachypus (Kraenzl.) Guillaumin in Guillaumin \& Rose, Bull. Mus. Natl. Hist. Nat., sér. 2, 31: 118. 1959. TYPE: Cameroon. Yaundé-Station, G. A. Zenker 420 (holotype, $\mathrm{B} \dagger$ ).

Angraecum cordatiglandulum De Wild., Bull. Jard. Bot. État Bruxelles 5: 184. 1916. Listrostachys cordatiglandula De Wild., Bull. Jard. Bot. État Bruxelles 5: 184. 1916, nom. illeg. Aerangis cordatiglandula (De Wild.) Schltr., Beih. Bot. Centralbl. 36(2): 121. 1918. TYPE: Democratic Republic of the Congo. Haut-Uele: Environs de Nala, F. Seret 754 (holotype, BR! [BR-000000881480]).

Notes. The duplicates of the type gatherings of Angraecum rhipsalisocium and Listrostachys dactyloceras housed at $\mathrm{W}$ are here confirmed as holotypes, following Cribb (1989), Szlachetko and Olszewski (2001), and Figueiredo and Smith (2008). This is based on the analysis of the correspondence between Welwitsch and H. G. Reichenbach and the presence of original notes and drawings associated with the material kept at $\mathbb{W}$, which indicate that these duplicates were the only ones used by the author of the names (sensu Art. 9.1.b, Turland et al., 2018). We have also located an additional isotype of A. rhipsalisocium at LISU, which had not been cited in previous floristic treatments.

Podangis sect. Rangaeris (Schltr.) Farminhão \& D'haijère, comb. nov. Basionym: Aerangis sect. Rangaeris Schltr., Beih. Bot. Centralbl. 36(2): 121. 1918. Rangaeris (Schltr.) Summerh., Bull. Misc. Inform. Kew: 227. 1936.

Podangis muscicola (Rchb. f.) Farminhão \& D’haijère, comb. nov. Basionym: Aeranthes muscicola Rchb. f.,
Flora 48: 190. 1865. Epidorkis muscicola (Rchb. f.) Kuntze, Revis. Gen. Pl. 2: 660. 1891. Mystacidium muscicola (Rchb. f.) T. Durand \& Schinz, Consp. Fl. Afric. 5: 54. 1894. Listrostachys muscicola (Rchb. f.) Rolfe in D. Oliver \& auct. suc. (eds.), Fl. Trop. Afr. 7: 158. 1897. Aerangis muscicola (Rchb. f.) Schltr., Bot. Jahrb. Syst. 53: 599. 1915. Rangaeris muscicola (Rchb. f.) Summerh. in J. Hutchinson \& J. M. Dalziel, Fl. W. Trop. Afr. 2: 450. 1936. TYPE: Angola. Malanje: Pungo Andongo, Tunda Quilombo, Apr. 1857, F. M. J. Welwitsch 699 (holotype, W image! [W-0011604]; isotypes, BM! [BM000540213], COI!, K! [K-000306341], LISU! [LISU-221674]). Figure 4A-C.

Angraecum englerianum Kraenzl., Bot. Jahrb. Syst. 7: 333. 1886. Listrostachys engleriana (Kraenzl.) Kraenzl., Bot. Jahrb. Syst. 19: 254. 1894. Aerangis engleriana (Kraenzl.) Schltr., Bot. Jahrb. Syst. 53: 599. 1915. TYPE: Cameroon. Littoral: Mungo [Moungo], Sep. 1874, R. W. Buchholz s.n. (holotype, $\mathrm{B} \uparrow$; drawing, $\mathrm{K}$ !).

Mystacidium batesii Rolfe in D. Oliver \& auct. suc. (eds.), Fl. Trop. Afr. 7: 172. 1897. Angraecum batesii (Rolfe) Schltr., Westafr. Kautschuk-Exped.: 283. 1900, nom. illeg. Aerangis batesii (Rolfe) Schltr., Bot. Jahrb. Syst. 53: 599. 1915. Aerangis mixta Schltr., Beih. Bot. Centralbl. 36(2): 122. 1918. TYPE: Cameroon. Sud: Efulen, 20 Sep. 1895, G. L. Bates 382 (lectotype, here designated, K! [K000306340]; isolectotype, BM! [BM-000540209]).

Aerangis falcifolia Schltr., Bot. Jahrb. Syst. 53: 598. 1915. TYPE: Tanzania. Mbeya: Station Kyimbila, Mulinda Wald, Mar. 1913, A. F. Stolz 1960 (lectotype, here designated, K! [K-000306346]; isolectotype, LD scan! [LD-1220164]).

Angraecum solheidii De Wild., Bull. Jard. Bot. État Bruxelles 5: 191. 1916. Listrostachys solheidii De Wild., Bull. Jard. Bot. État Bruxelles 5: 191. 1916. Aerangis solheidii (De Wild.) Schltr., Beih. Bot. Centralbl. 36(2): 123 (1918). TYPE: Democratic Republic of the Congo. Tshopo: env. de Yambuya, s.d., A. F. Solheid 127 (lectotype, here designated, BR! [BR-0000008814814]; isolectotype, BR! [BR-0000008814821]).

Listrostachys floribunda Rolfe, Bull. Misc. Inform. Kew 1918: 236. 1918. Aerangis floribunda (Rolfe) Summerh., Bull. Misc. Inform. Kew 1932: 509. 1932. TYPE: Uganda. Umpala, s. coll., s.n. (holotype, K! [K-000306345]).

Notes. Podangis muscicola presents two different leaf habits. Numerous specimens from East and Southeast Africa, as well as specimens from Central Africa growing as lithophytes (e.g., V. Droissart 1319 [BRLU!]), present arcuate, strongly conduplicate leaves, more reminiscent in habit to species in section Podangis (see Fig. 4A), whereas most other specimens from West and Central Africa present straight and not strongly conduplicate leaves (see Fig. 4C). These differences are possibly due to either ecotypical variation or phenotypic plasticity related to sunlight exposure. Specimens of $P$. muscicola in herbaria generally tend to blacken after being dried, whereas those of $P$. dactyloceras and 


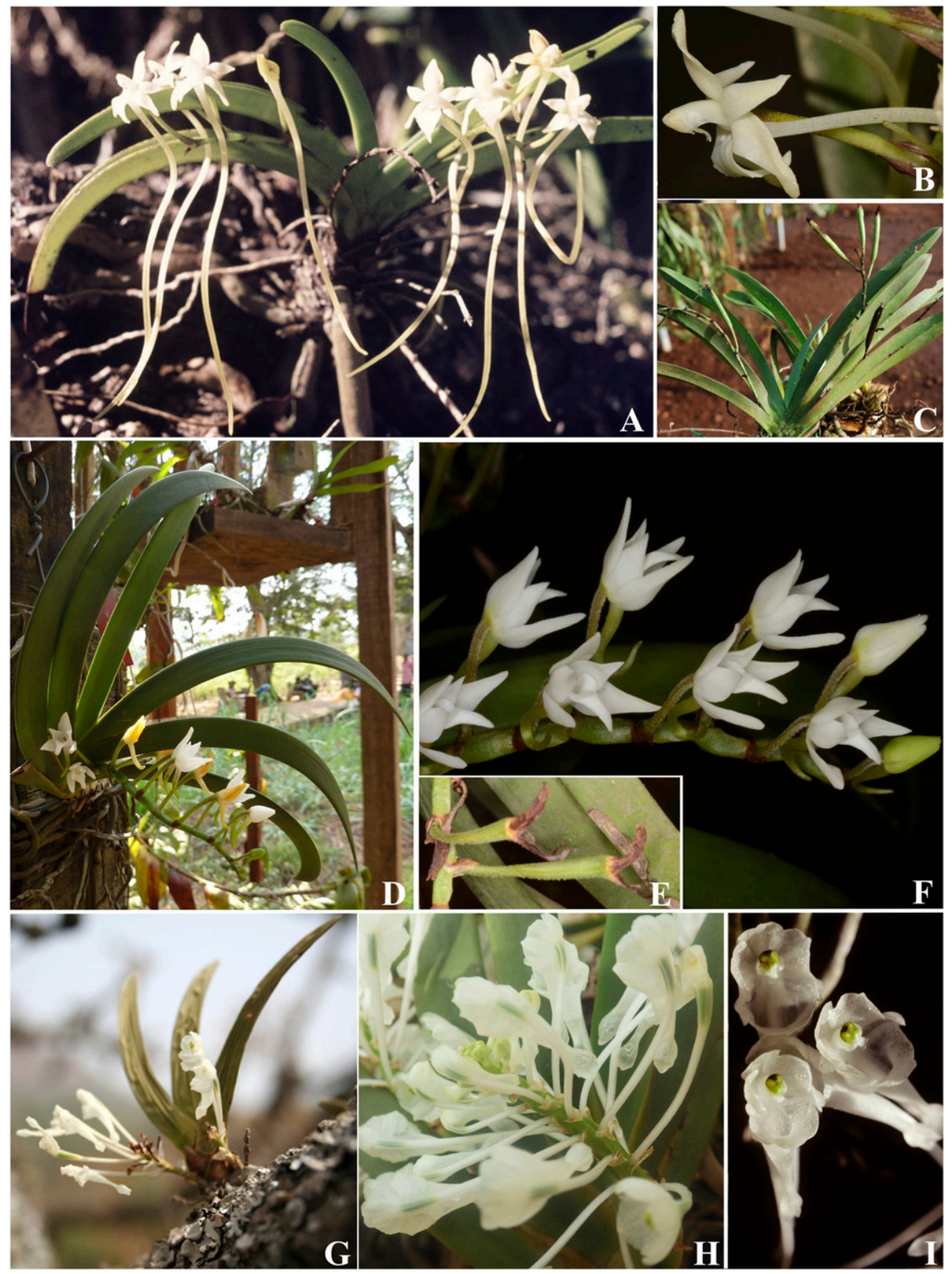

Figure 4. Overview of Podangis Schltr. A-C. Podangis muscicola (Rchb. f.) Farminhão \& D’haijère. —A. Habit of a plant with arcuate and strongly conduplicate leaves from Mazumbai (Tanzania). - B. Flower, side view, recorded in Lualaba, Kakanda (Democratic Republic of the Congo). - C. Habit of a fruiting plant with straight conduplicate leaves, cultivated at the Nimba shade house (Guinea). D-F. Podangis rhipsalisocia (Rchb. f.) P. J. Cribb \& Carlsward. -D. Habit of a plant grown at the University of Yaoundé I shade house (Cameroon). —E. Inflorescence, taken at the Nimba shade house (Guinea). - F. Immature fruits, recorded at Nimba shade house (Guinea). G-I. Podangis dactyloceras (Rchb. f.) Schltr. —G. Habit, recorded in Mpati Hill (Cameroon). —H. Inflorescence, taken at the University of Yaoundé I shade house (Cameroon). - I. Flowers, face view (Tanzania). A by C. GrayWilson via the World Orchid Iconography; B by Warren McCleland via Senckenberg's West African Plants; C and E by E. Bidault; D by Murielle Simo-Droissart; G by Marco Schmidt via Senckenberg's West African Plants; H by G. Kamdem; and I by W. Bachmann via the World Orchid Iconography. 
$P$. rhipsalisocia tend to stay green. The duplicate of the type gathering of Aeranthes muscicola housed at W is here confirmed as the holotype, following Cribb (1989: 572), Szlachetko and Olszewski (2001: 676), and Figueiredo and Smith (2008: 193). In relation to the Angolan collections of Friedrich Welwitsch, Albuquerque et al. (2009) suggest that names published based on specimens sent to specialists before Welwitsch's death are to be typified by material in the herbarium of the author of the name. The duplicate at $\mathrm{W}$ is the only one with associated original notes and drawings of Heinrich Gustav Reichenbach and with a direct reference to the protologue handwritten by Reichenbach himself. Furthermore, based on the analysis of the correspondence between Welwitsch and Reichenbach in the year of the publication of the name (Natural History Museum's Library and Archives, 2019), it is likely that the specimen found at $\mathrm{W}$ was the only one used by Reichenbach (sensu Art. 9.1.b, Turland et al., 2018). We have also located additional isotypes at COI and LISU, which had not been cited in previous floristic treatments. Concerning the typifications of Mystacidium batesii and Angraecum solheidii De Wild., both heterotypic synonyms of $P$. muscicola, we chose as lectotypes the syntypes gathered by the eponymous collectors. Finally, an additional duplicate of the type series of Aerangis falcifolia Schltr. was almost certainly housed at $\mathrm{B}$ and destroyed during the bombing of the Berlin Herbarium.

\section{NEW GenERA}

Aziza Farminhão \& D'haijère, gen. nov. TYPE: Rangaeris trilobata Summerh., Bull. Misc. Inform. Kew 1936: 229. 1936.

Diagnosis. Aziza Farminhão \& D'haijère is vegetatively most similar to Solenangis Schltr. and Dinklageella Mansf., with which it shares a scandent habit with elongate internodes and clasping crozier-shaped root apices, but differs in inflorescence structure (pendent with peduncle as long as or longer than rachis vs. suberect with peduncle shorter than rachis in Solenangis), column structure (prominent column projecting well above the sepals and petals and an anther cap with a truncate apex vs. small column, shorter than sepals and an anther cap with an acute apex in Solenangis), in the pollinarium (two stipes vs. a single stipes in Solenangis), and fruit morphology (narrowly ellipsoid capsules, 6 to 7 times as long as wide vs. ellipsoid to narrowly ellipsoid capsules 1.5 to 3.5 times as long as wide in Solenangis). From any other species of the Cyrtorchis-Tridactyle alliance, including those formerly placed in Rangaeris (Schltr.) Summerh., it differs in its scandent habit and climbing roots with crozier-shaped apices. From Podangis Schltr. (including Rangaeris muscicola (Rchb. f.) Summerh.) it also differs in its pendent inflorescences (vs. erect to suberect), deeply trilobed (vs. entire or subentire) lip, the structure of the column (apterous in Aziza vs. with prominent spreading wings adnate to lip base in Podangis), and the shape of the viscidium (truncate anterior margin vs. notched anterior margin in Podangis).
Etymology. The name of this monospecific genus commemorates the homonymous miniature forest-dwelling figures of Dahomey mythology. According to some descriptions, Aziza are fairylike creatures with a single long hair that covers them entirely and makes them invisible, controlling the hunt and all that pertains to the forest (Blier, 1996). The gender is feminine.

Aziza trilobata (Summerh.) Farminhão \& D'haijère, comb. nov. Basionym: Rangaeris trilobata Summerh., Bull. Misc. Inform. Kew 1936: 229. 1936. Solenangis trilobata (Summerh.) R. Rice, Oasis 3: 14. 2006. TYPE. Nigeria. Akwa Ibom: Eket Distr., 1912-1913, P. A. Talbot \& D. A. Talbot 3299 (holotype, BM! [BM000540223]; isotype, K! [K000306411]). Figures 5, 6A-C.

Scandent, epiphytic herb, monopodial. Roots numerous, produced all along the stem, branching, slender, tortuous, 0.5-2 mm diam., grayish to brownish; apex crozier-shaped clinging to other roots and surrounding vegetation. Stem pendent or climbing, leafy, covered by leaf sheaths, with elongate internodes, up to $60 \times$ $0.2-0.35 \mathrm{~cm}$. Leaves numerous, alternate and distichous, articulated to sheathing base, spaced $3-5 \mathrm{~cm}$ apart; lamina 4-10.8 ×0.7-1.7 cm, elliptic to narrowly elliptic, thin-textured, flat, margin entire, bifid or unequally and acutely bilobed at apex with no notch, light to dark green. Inflorescence a secund raceme, axillary, pendent, lax, 2- to 9-flowered, 3-23.1 cm, axis dark green to brownish; peduncle up to $13.2 \mathrm{~cm}$, covered by up to 5 dark brown ochreate sterile bracts, $3.5 \mathrm{~mm}$; rachis terete, flexuose, sparsely lepidote, floral node 9-17 mm; floral bracts inconspicuous, $3.5 \mathrm{~mm}$, ochreate, barely sheathing floral pedicels, dark brown. Flowers whitish, turning salmon to dull brownish orange in late anthesis, stellate, resupinate; sepals and base of petals pinkish orange; dorsal surface of sepals and spur clothed with brown scales; lip white with greenish spur, petals cream, all tepals convex and markedly reflexed; column white; anther cap cream, pollinia light yellow. Dorsal sepal 7.5-9.5 × 3-4 mm, ovate, sharply constricted in apical third, obtuse, entire. Lateral sepals 8.5-10 × 2.5-3.5 mm, narrowly ovate, sometimes slightly falcate, obtuse, entire. Petals 7.5-10 $\times$ 1.5-2.5 mm, narrowly triangular, acute, entire but sometimes obscurely trilobed at base. Lip 8.5-10 $\times$ 4.5-8 mm, trilobed, ecallose; median lobe 7-8 $\times$ 1.5-3 mm, narrowly triangular, obtuse, entire; lateral lobes $1.5-3 \times 1.5-3 \mathrm{~mm}$, subreniform, anterior margin crenate to asymmetrically dentate, posterior margin entire; lip spur 5-6.1 cm, filiform, tapering toward apex, pendent, helically twisted. Column 4.5-6 $\times 2 \mathrm{~mm}$, exposed; stigma $1.5 \times 2 \mathrm{~mm}$, subcircular, concave, lower rim prominent, forming an acute downward- 

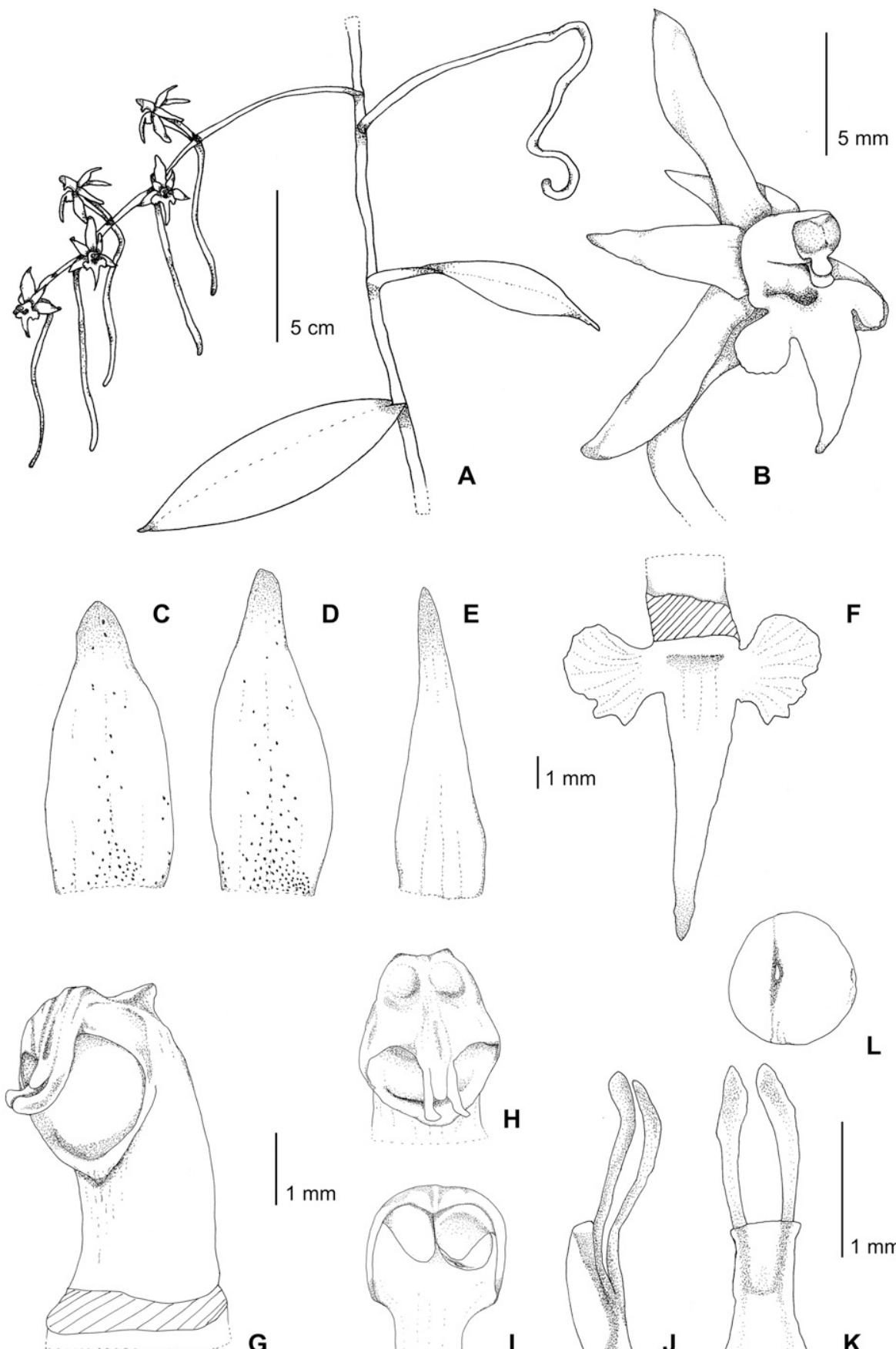

$\mathbf{L}$

T. D'HAIJERE

G

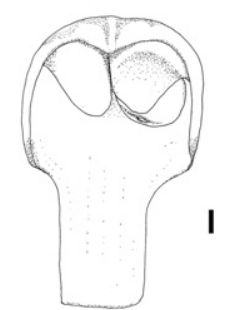

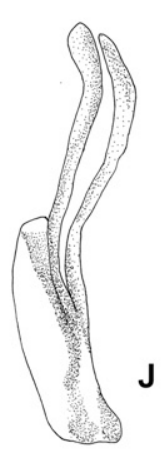

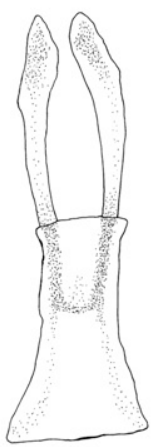

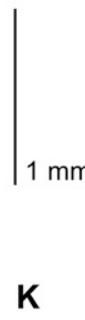

K

Figure 5. Aziza trilobata (Summerh.) Farminhão \& D’haijère. —A. Habit. —B. Flower. —C. Dorsal sepal. —D. Lateral sepal. —E. Petal. —F. Lip. —G. Column, lateral view. - H. Column, face view. -I. Anther cap, ventral view. —J. Pollinaria, dorsal view. -K. Pollinaria, ventral view. - L. Pollinium. A from Stévart, Leal \& Nguema 2467 (BRLU); B adapted from a photo of a plant in cultivation in Tchimbélé (Gabon); C-F, J, K from Stévart 662 (BRLU); G from Primo \& Stévart 71 (BRLU); H from Farminhão 11 (BRLU); I and L from Stévart, Ngok \& Mendu 1121 (BRLU). Drawn by Tania D’haijère. 

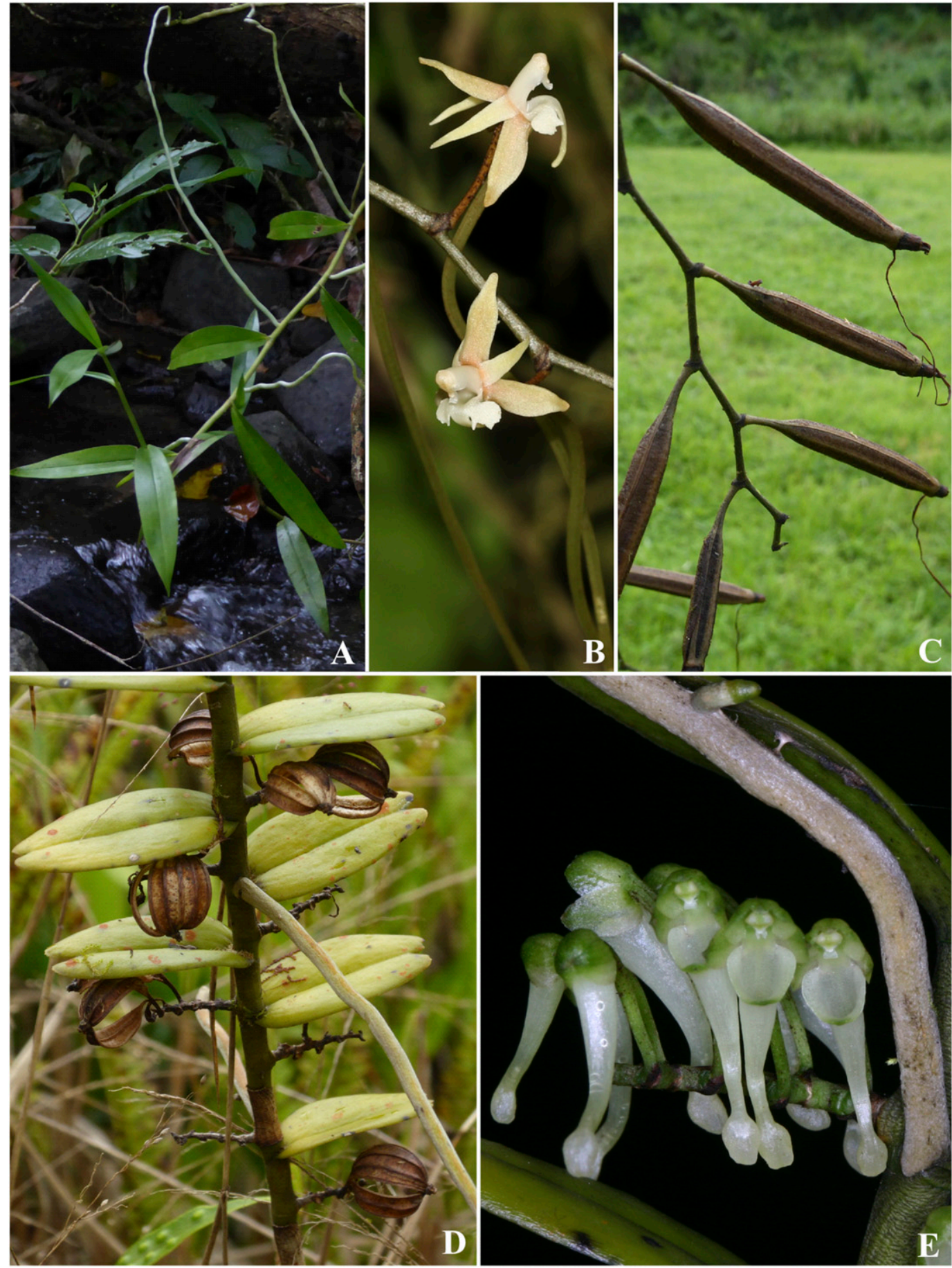

Figure 6. Overview of Aziza Farminhão \& D'haijère and Solenangis Schltr. A-C. Aziza trilobata (Summerh.) Farminhão \& D'haijère. - A. Habit, plant growing over a small stream in the forest (D'haijère et al. 137). —B. Flowers (Dewynter s.n.). -C. Fruits (D'haijère et al. 2). D, E. Solenangis clavata (Rolfe) Schltr. -D. Old fruits of a plant growing in Lagoa Amélia crater bog (São Tomé). - E. Inflorescence (São Tomé). A, C, D by João N. M. Farminhão; B by Maël Dewynter/Fondation Biotope pour la biodiversité; and E by Tariq Stévart. 


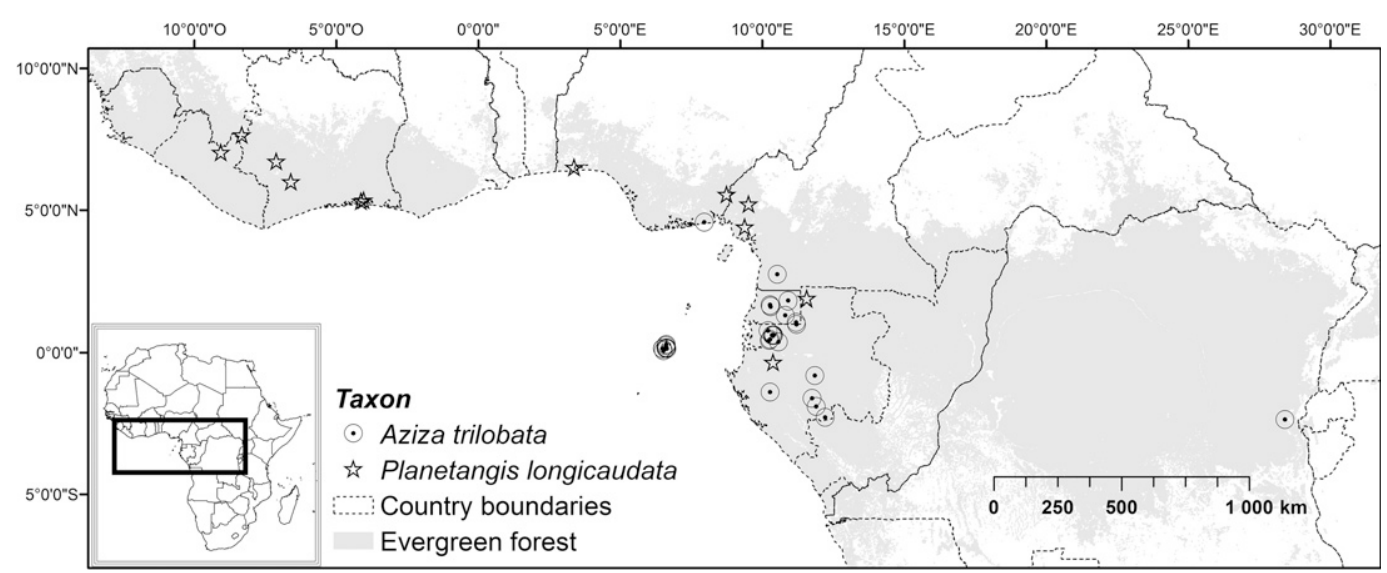

Figure 7. Geographical distribution of Aziza trilobata (Summerh.) Farminhão \& D’haijère and Planetangis longicaudata (Rolfe) Stévart \& Farminhão in tropical Africa.

projecting callus; anther cap $2.5 \times 1.5 \mathrm{~mm}, 1 \mathrm{~mm}$ tall, cucullate, with a truncate beaklike expansion covering the rostellum; pollinia 2, globose, porate, dark brown when preserved in spirit; stipes $2,1.5 \mathrm{~mm}$, linear, slightly clavate, insertion point halfway along length of viscidium, turning yellowish brown when preserved in spirit; a single viscidium, $1 \mathrm{~mm}$, saddle-shaped with a truncate anterior margin, whitish, hyaline, turning green when preserved in spirit; rostellum trifid, midlobe oblong, rounded, lateral lobes ca. $1.5 \times$ as long as midlobe, pendulous and upcurved, parallel to each other, linear, apices rounded. Ovary and pedicel 9-13 mm, slender, light brown densely covered in dark brown scales. Fruit a narrowly ellipsoid capsule, triquetrous, up to $4.3-4.7 \times$ 0.25-0.5 cm, brown, often with a marcescent lip spur.

Phenology. Aziza trilobata typically flowers from July to January, but some old collections record flowering in April (e.g., G. M. P. C. Le Testu 5405) and May (C. F. A. Onochie \& M. G. Latilo 32937). Fruits have been recorded from October to May.

Habitat and ecology. This species is a low or canopy shade scandent epiphyte in lowland and submontane evergreen rainforest (Stévart \& Oliveira, 2000). It is often found in inundated and riparian forest, namely near waterfalls, where it is most commonly observed climbing on low vegetation. It also occurs in the herbaceous, shrubby, and forest-fringe communities of the inselberg-rainforest ecotone (Droissart et al., 2009).

Distribution. Aziza trilobata is found in Lower Guinea (western Nigeria, Cameroon, Rio Muni, and Gabon), Gulf of Guinea Islands (São Tomé and possibly Príncipe; Stévart \& Oliveira, 2000), and the Congolian Region (Democratic Republic of the Congo) in Central tropical Africa, at elevations of 10-1550 m. Figure 7.
Conservation status. The species is given an IUCN Red List status of Least Concern [LC]. The EOO of Aziza trilobata is estimated to be $869,144 \mathrm{~km}^{2}$, far exceeding the $20,000 \mathrm{~km}^{2}$ upper limit for Vulnerable status under the criterion B1. Its AOO is estimated to be $120 \mathrm{~km}^{2}$, which falls within the limits for Endangered status under the criterion B2. The species is known from 30 subpopulations in Nigeria, Rio Muni, Gabon, São Tomé, and the Democratic Republic of the Congo. Aziza trilobata is an epiphyte in lowland and submontane evergreen rainforest, between 10 and $1100 \mathrm{~m}$ elevation. Several collections of $A$. trilobata come from four protected areas: two in Rio Muni (Monte Alén National Park and Piedra Bere Natural Monument), one in Gabon (Monts de Cristal National Park), and one in São Tomé (Obô Natural Park). These sites are not under threat and appear well managed. The other collections of the species are documented from unprotected sites, some of which are currently subjected to great human pressure, especially from shifting agriculture, selective logging, and timber harvesting for small-scale subsistence. A total of 30 subpopulations of the species are identified, representing 19 different locations (sensu IUCN, 2019), much more than 10 locations, which is the upper limit for Vulnerable status under the subcriterion $a$ of criterion B2. Notwithstanding these human activities, with varying levels of impact, the number of subpopulations of A. trilobata, as well as its EOO and AOO, likely will not decrease substantially in the near future. Since the conditions for applying subcriteria $a$ and $c$ under criterion $\mathrm{B} 2$ are not met, IUCN criteria therefore indicate that the species cannot be regarded as Endangered even though its AOO falls below the threshold of $500 \mathrm{~km}^{2}$ for criterion B2. Aziza trilobata is thus assigned a preliminary status of LC. 


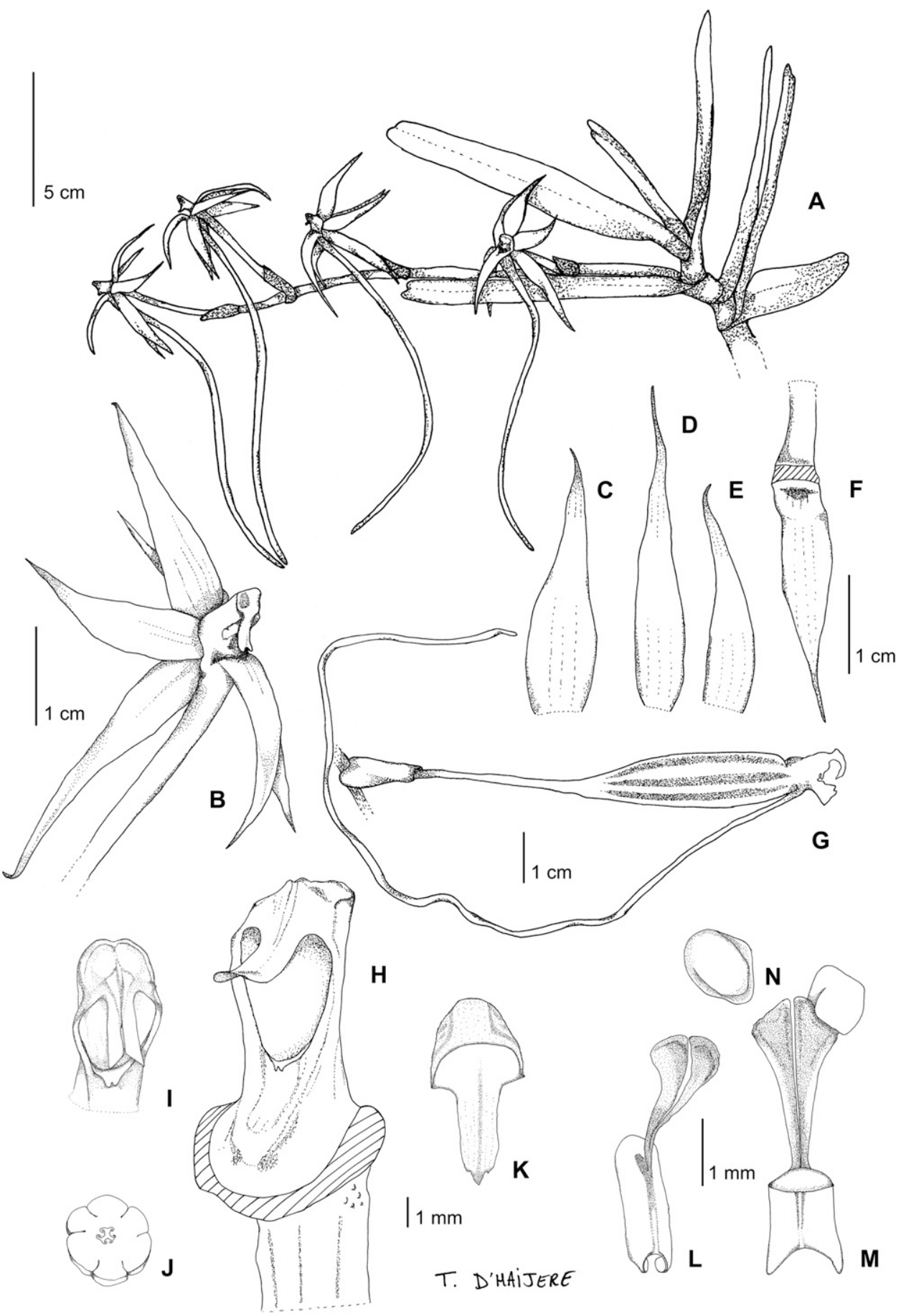

Figure 8. Planetangis longicaudata (Rolfe) Stévart \& Farminhão. — A. Habit. —B. Flower. —C. Dorsal sepal. —D. Lateral sepal. —E. Petal. —F. Lip. —G. Developing fruit with marcescent lip spur. —H. Column. —I. Column, face view. —J. Ovary, transversal cut. -K. Anther cap, ventral view. - L. Pollinaria, dorsal view. - M. Pollinaria, ventral view with one pollinium in situ. - N. Pollinium. A adapted from a photograph of Pérez-Vera (2003). B from a photograph of a plant in cultivation in Libreville (BTO 440). C-F from GAB 583. G from Simo \& Zapfack SIP 124 (BRLU). H-N from GAB 668. Drawn by Tania D'haijère. 


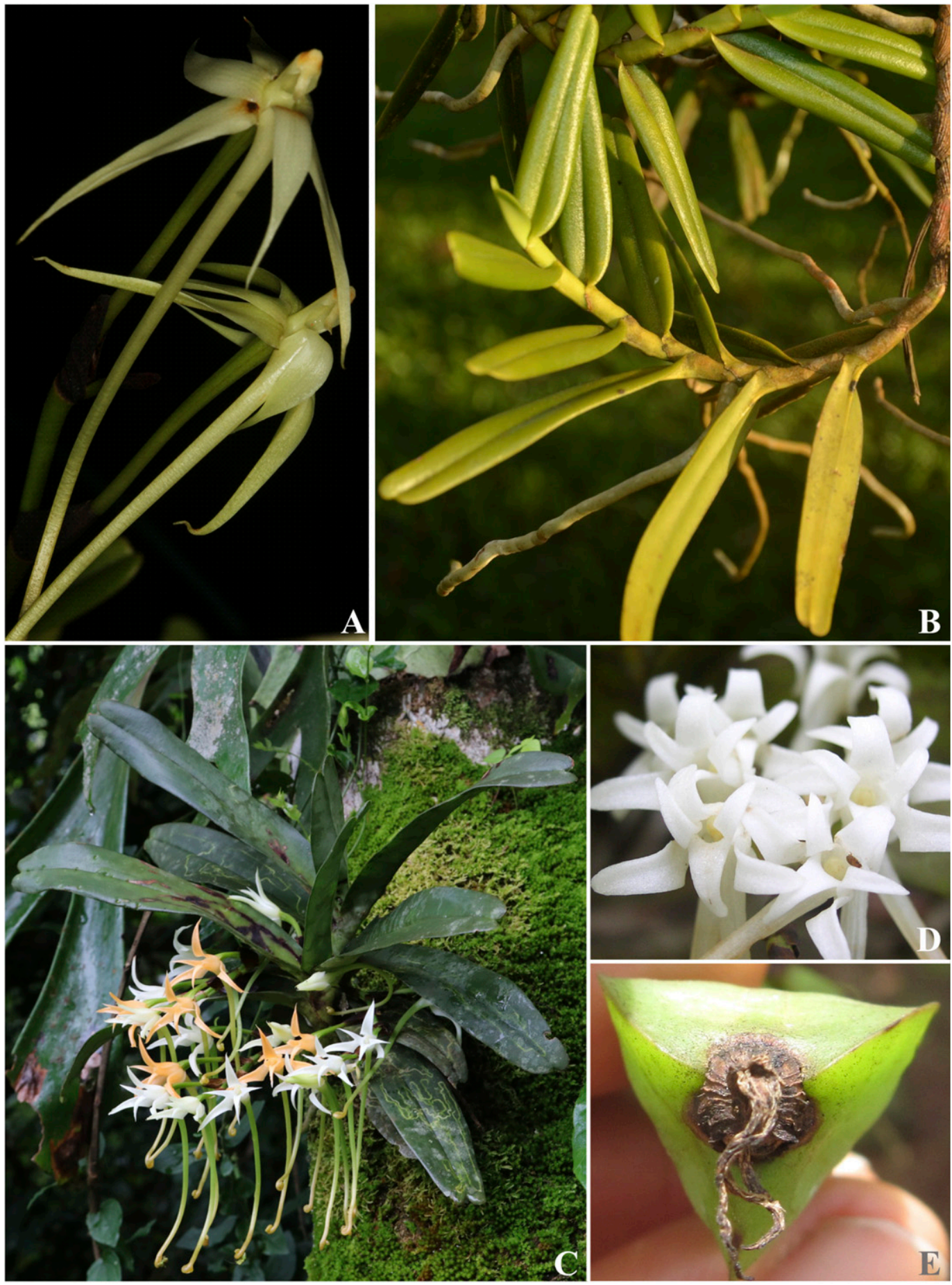

Figure 9. Overview of Planetangis Stévart \& Farminhão and Cyrtorchis Schltr. A, B. Planetangis longicaudata (Rolfe) Stévart \& Farminhão. - A. Flowers, face view, cultivated at Jardi-Gab shade house (Gabon). —B. Habit, cultivated at Jardi-Gab shade house (Gabon). - C. Cyrtorchis letouzeyi Szlach. \& Olszewski, habit, Dja Faunal Reserve (Cameroon). —D. Cyrtorchis ringens (Rchb. f.) Summerh., flowers, face view, grown at the University of Yaoundé I shade house (Cameroon). - E. Cyrtorchis chailluana (Hook. f.) Schltr., fruit, face view, grown at the University of Yaoundé I shade house (Cameroon). A and B by Tariq Stévart; C by V. Droissart; D by G. Kamdem; and E by Laura Azandi. 
Notes. The phylogenetic position of Aziza trilobata is not fully resolved, but it appears to be an isolated lineage in the Cyrtorchis-Tridactyle clade. A more comprehensive molecular dataset, with more samples and markers, is needed to disentangle further the relationships between genera in the Cyrtorchis-Tridactyle clade, but the evidence already seems sufficient to conclude that A. trilobata is evolutionarily isolated and warrants recognition as a distinct genus.

The lack of records of Aziza trilobata between southwestern Nigeria and southern Cameroon-Rio MuniGabon is probably due in part to a collecting gap in Bioko and Cameroon, namely around Mount Cameroon, where species distribution modeling predicts its occurrence with a high probability (Deblauwe et al., 2016). The recent discovery of $A$. trilobata in Mulolo Forest (Shabunda Territory), in eastern Democratic Republic of the Congo, has significantly expanded its extent of occurrence. Further fieldwork in the Congo Basin would likely reduce the current distributional gap between Atlantic Central Africa and South Kivu.

The crenation/dentation of the anterior margin of the lateral lobes of the lip of Aziza trilobata presents a great degree of asymmetry, with one lobe often presenting larger teeth than the other. This can be interpreted as a case of fluctuating asymmetry, which is a relatively little-studied phenomenon in plants (Rudall et al., 2002).

Additional specimens examined. NIGERIA. Akwa Ibom: Eket, Big town, on path from village to Western boundary of Stubbs Creek F.R., 13 May 1953, Onochie \& Latilo 32937 (FHI, K). CAMEROON. Sud: Akom II (rte. Kribi-Ebolowa, campement à $3 \mathrm{~h}$ de marche au $\mathrm{S}$ du village, sommet à $3 \mathrm{~h}$ de marche au $\mathrm{N}$ du campement, N2 ${ }^{\circ} 44^{\prime} 20.04^{\prime \prime}$ E10 ${ }^{\circ} 31^{\prime} 55.92^{\prime \prime}$, 1075 m, 4 June 2006, Droissart 132 (BRLU). EQUATORIAL GUINEA (RIO MUNI). Centro Sur: Mirador, dalle rocheuse de Monte Alén, $3 \mathrm{~km}$ à l'O de la station Ecofac (Parc Nat. de Monte Alén), $\mathrm{N}^{\circ} 40^{\prime} \mathrm{E} 10^{\circ} 17^{\prime}, 1200 \mathrm{~m}, 1$ July 1999, T. Stévart 589 (BRLU); ibid. loc., 1100 m, 5 Feb. 2001, T. Stévart 755 (BRLU); Parc National de Monte Alén, dalle rocheuse d'Engong, $5 \mathrm{~km}$ à l'ouest du Village d'Engong, $\mathrm{N1}^{\circ} 37^{\prime} \mathrm{E} 10^{\circ} 18^{\prime}$, 1100 m, 11 May 2002, Parmentier \& Esono 2794 (BRLU). Wele-Nzas: Mungum (inselberg de), à 45 minutes de marche du village de Kukumancoc, N1 ${ }^{\circ} 19^{\prime}$ E10 $49^{\prime}$, 735 m, 24 May 2002, Stévart, Ndong Bokung \& Ndong Maye 1537 (BRLU); inselberg de Akoak Ebanga, à $1 \mathrm{~h}$ de marche du village de Ngong Mocomo, à $10 \mathrm{~km}$ de Nsork, $\mathrm{N1}^{\circ} 04^{\prime} \mathrm{E} 11^{\circ} 12^{\prime}, 570 \mathrm{~m}, 31$ May 2002, Parmentier \& Esono 3521 (BRLU). S. loc: inselberg, 25 June 1999, Parmentier \& Nguema 1128 (BRLU). GABON. Woleu-Ntem: Inselberg de Ntan (Bikougou), à $1 \mathrm{~h}$ 30 de marche du village de La Hollande (à $2 \mathrm{~km}$ de Sam), 790 m, 22 Jan. 2000, Parmentier \& Nguema 790 (BRLU). Estuaire: Mont Séni (Ekoko), 2 Oct. 2002, Stévart 1781 (BRLU); ca. $10 \mathrm{~km}$ along the rd. Tchimbele-Kinguele, N0 $37^{\prime}$ E10 $21^{\prime}, 620$ m, 27 Jan. 1986, van der Laan 1332 (WAG); ibid. loc., 22 Nov. 1993, Arends 1011 (WAG); Tchimbélé (carrière de) près du bras mort du lac, N0 $37^{\prime} 8.93^{\prime \prime}$ E10 $24^{\prime} 4.21^{\prime \prime}, 570$ m, 7 Sep. 2002, Stévart 1808 (BRLU); Tchimbélé hydroelectric compound, around houses, N0³7'13" E10²4'26", 543 m, 21 Nov. 2002, Strijk 450 (WAG); Tchimbélé, forêt aux environs du barrage, N0 $36^{\prime} 8.78^{\prime \prime}$ E10 $24^{\prime} 1.68^{\prime \prime}, 25$ Sep. 2001, 460 m, Stévart et al. 1098 (BRLU); ibid. loc., 23 Sep. 2002, Stévart 1747 (BRLU); Tchimbélé, ancien lit de la rivière qui descend du barrage, N0³6'8.41" E10 $23^{\prime} 9.95^{\prime \prime}, 440$ m, 8 Sep. 2001, Stévart et al. 1121 (BRLU); Monts de Cristal, cascade sur la rive Est de la Mbé, juste au-dessus de Kinguélé, $\mathrm{NO}^{\circ} 27^{\prime} 48^{\prime \prime}$ E10 ${ }^{\circ} 16^{\prime} 52^{\prime \prime}, 140$ m, 25 Oct. 2017, D'haijère et al. 2 (BRLU, LBV); Lower Mbé Valley, SW from Kinguelé \& NE from Mfoul Mengoma, at the foot of Mt. Mbilan, N0 25'37" E10 $15^{\prime} 13^{\prime \prime}$, 121 m, 26 Oct. 2017, Farminhão et al. 11 (BRLU); Monts de Cristal, Upper Komo Valley, SEEF concession area, ca. $4.5 \mathrm{~km}$ SE from Violaineville, N0 $22^{\prime} 37^{\prime \prime} \mathrm{E} 10^{\circ} 34^{\prime} 33^{\prime \prime}$, 485 m, 4 Nov. 2017, Farminhão et al. 52 (BRLU). Ngounié: Massif du Chaillu, Bouvala area, Mont Songo, $1^{\circ} 38^{\prime} 58.3^{\prime \prime} \mathrm{S}$ $11^{\circ} 45^{\prime} 47.6^{\prime \prime} \mathrm{E}, 790$ m, 5 Oct. 2007, Stévart, Leal \& Nguema 2467 (BRLU); dans la haute Ngounyé, chute de la Mboumi à Mbigou, 30 Apr. 1927, Le Testu 5405 (BM); ibid. loc., 2 Apr. 1927, Le Testu s.n. (K); Balamboula (près de), $2^{\circ} 17^{\prime} 3.52^{\prime \prime} \mathrm{S}$ $12^{\circ} 13^{\prime} 11.26^{\prime \prime} \mathrm{E}, 620 \mathrm{~m}$, Dewynter s.n. (BRLU [photo]). SÃO TOMÉ AND PRÍNCIPE. São Tomé: Morro Chamiço, N $0^{\circ} 17^{\prime} 0^{\prime \prime} \mathrm{E}$ 6³7'30', 1100 m, 1 Sep. 1999, Stévart 662 (BRLU); ibid. loc., 12 Aug. 2002, Primo \& Stévart 71 (BRLU); Bombaim, entre la Roça et Formoso Pequeno, N0 $14^{\prime} 46.86^{\prime \prime} \mathrm{E}^{\circ} 37^{\prime} 0.90^{\prime \prime}, 504 \mathrm{~m}, 2$ Dec. 2017, D'haijère et al. 137 (BRLU); Pico Maria Fernandes, N0 ${ }^{\circ} 10^{\prime}$ E06 38', 150 m, 26 Aug. 1997, Stévart \& Oliveira 91 (BRLU); ibid. loc., 11 Oct. 1997, Stévart 261 (BRLU); ibid. loc., N0 ${ }^{\circ} 10^{\prime} 15^{\prime \prime}$ E $6^{\circ} 38^{\prime} 30^{\prime \prime}, 150 \mathrm{~m}$, 1 Sep. 1999, Stévart 677 (BRLU); Rio Ió Grande, s.d., $\mathrm{N0}^{\circ} 9^{\prime} 45^{\prime \prime} \mathrm{E}^{\circ} 36^{\prime} 45^{\prime \prime}, 200$ m, Stévart 703 (BRLU); ibid. loc., 20 Aug. 2002, Primo \& Stévart 80 (BRLU); margem do Rio Yo Grande, 1999, Oliveira 137/1999 (BRLU); Vale Carmo, bordo do caminho, N09’ E 6³7', 259 m, 14 Sep. 2007, Oliveira 1087 (BRLU); Angolares, Lagoa, Angra de São João, Jan. 1886, Quintas 1028 (BM, COI); Rio Xufexufe, $\mathrm{NO}^{\circ} 08^{\prime} \mathrm{E} 6^{\circ} 30^{\prime}, 230 \mathrm{~m}$, 1 Oct. 1997, Stévart 203 (BRLU). DEMOCRATIC REPUBLIC OF THE CONGO. SudKivu: Shabunda, Itanga/Mulolo, N0 $10^{\prime} 15^{\prime \prime}$ E $6^{\circ} 38^{\prime} 30^{\prime \prime}, 1532 \mathrm{~m}$, 13 Dec. 2018, L. Dumbo 16 (LWI).

Planetangis Stévart \& Farminhão, gen. nov. TYPE: Rangaeris longicaudata (Rolfe) Summerh. Basionym: Mystacidium longicaudatum Rolfe in D. Oliver \& auct. suc. (eds.), Fl. Trop. Afr. 7: 170. 1897.

Diagnosis. Planetangis Stévart \& Farminhão is most similar to Cyrtorchis Schltr., with which it shares white, stellate flowers; a lip similar in shape to the remaining tepals; two stipes clearly broadening toward the apex; and connivent lateral rostellar lobes, but differs in the markedly deflexed petals exposing the column (vs. column covered by petals); the elongate column, about twice as long as wide (vs. column very short, about as long as wide); the deeply concave stigma, obovate, in which the lower margin bears a small bilobed callus and does not touch the entrance of the lip spur (vs. stigma slightly concave, oblong, the lower margin touching the entrance of the lip spur); the saddle-shaped viscidium, triangular when flattened, with a deeply bilobed anterior margin, where the insertion point of the stipes is at half of its length (vs. viscidium either linear and hyaline or triangular comprising an indurate saddle-shaped proximal part and a hyaline distal part, in both cases with bifid anterior margin and the insertion point of the stipes at the rear third of its length); the rostellum, which is exposed and presents broad lateral lobes, not tapering, and beveled at the apex (vs. rostellum sunken into mouth of the spur, with tapering lateral lobes acute at the apex); and the rounded cross-section of the ovary and fruits (vs. triquetrous ovary and often fruit). It differs 
from Podangis Schltr. based on the previously mentioned traits shared with Cyrtorchis (vs. lip dissimilar in shape to remaining tepals, two stipes only slightly broadening toward the apex, and parallel lateral rostellar lobes). It also superficially resembles Aerangis Rchb. f., but differs in having erect to suberect inflorescences (vs. pendent) and pollinaria with two stipes (vs. a single stipe).

Etymology. The name of this monospecific genus derives from the ancient Greek stem planēt-, which literally translates to "wanderer" and ángos, "vessel." This refers to the puzzling taxonomic position of this satellite taxon in the Cyrtorchis-Podangis clade, and the ending -angis alludes to other angraecoid generic names such as Aerangis and Podangis with which it shares the same overall floral habit. The name's gender is feminine.

Planetangis longicaudata (Rolfe) Stévart \& Farminhão, comb. nov. Basionym: Mystacidium longicaudatum Rolfe in D. Oliver \& auct. suc. (eds.), Fl. Trop. Afr. 7: 170. 1897. Rangaeris longicaudata (Rolfe) Summerh. in J. Hutchinson \& J. M. Dalziel, Fl. W. Trop. Afr. 2: 449. 1936. TYPE: Nigeria. Lagos: Lagos, 26 Mar. 1896, H. Millen 188 (holotype, K! [K-000306412]). Figures 8, 9A, B.

Erect to suberect epiphytic herb, monopodial, often forming large clumps. Roots stout, branching, emerging all along stem, 3.5-4 mm in diam., grayish. Stem pendent to suberect, leafy, covered by leaf sheaths, with elongate leaf nodes, up to $18.1 \mathrm{~cm}$ long, 5-6 mm diam. Leaves numerous, alternate and distichous, articulated to a sheathing base, spaced 1-2 cm; lamina 6-12 $\times$ $1-1.8 \mathrm{~cm}$, narrowly oblong, fleshy and very coriaceous, revolute, margin entire, emarginate to unequally bilobed at apex with rounded lobes, light green to dark green above and grass-green beneath. Inflorescence a secund raceme, axillary, suberect to erect, lax, 3- to 8flowered, 8-20 cm; axis light green; peduncle up to $6 \mathrm{~cm}$, covered by 2 to 3 dark brown ochreate sterile bracts, 10-12 mm; rachis terete, flexuose, glabrous, floral node 25-35 mm; floral bracts prominent, 10-16 $\mathrm{mm}$, broadly triangular, markedly sheathing floral pedicels, obtuse, dark brown. Flowers ivory white turning yellowish in late anthesis, stellate, resupinate; all tepals white, glabrous, convex, markedly reflexed, narrowly ovate, caudate, and with entire margin; lip spur white to greenish becoming orange toward tip; column white, anther cap orange turning dark brown when senescent. Dorsal sepal $20-32 \times 5.5-8 \mathrm{~mm}$. Lateral sepals 28-36 × 4.5-6 mm. Petals 21-27 × 4.5-6 mm. Lip 24-30 × 4-5 mm, subsimilar to other tepals, ecallose; lip spur 15-20.3 cm, filiform with a narrowly conical mouth and tapering toward apex, pendent, not twisted. Column 6-8 $\times 3-4 \mathrm{~mm}$, exposed; stigma $4.5 \times 3 \mathrm{~mm}$, obovate, deeply concave, lower rim prominent forming a small bilobed downward-projecting callus; anther cap
$6 \times 3 \mathrm{~mm}, 2 \mathrm{~mm}$ tall, cucullate, with a tridentate beaklike expansion covering the rostellum; pollinia 2 , subglobose, cleft, dull brownish yellow when preserved in spirit; stipes $2,3.5 \mathrm{~mm}$, obtriangular, much broadened at apex, insertion point halfway along length of viscidium, dull brownish yellow when preserved in spirit; a single viscidium, $3 \mathrm{~mm}$, saddle-shaped, triangular when flattened, with a deeply bilobed anterior margin, whitish, hyaline; rostellum trifid, midlobe triangular, acute, inconspicuous, lateral lobes prominent, ca. $2 \times$ as long as midlobe, pendulous, connivent, linear, with broadly beveled apices. Ovary and pedicel with a rounded cross section, 4.6-7.1 cm, green, glabrous. Fruit an ellipsoid capsule, constricted toward base, ribbed, $3.8 \times 0.9 \mathrm{~cm}$, often with marcescent lip spur.

Phenology. Planetangis longicaudata typically flowers from October to January, but a single flowering specimen (H. Millen 188, the type, from 1896) was recorded at the end of March. Flowers are reported to last from two to three weeks (Pérez-Vera, 2003). The single known record of a fruit (P. Simo \& L. Zapfack SIP 124) dates from December.

Distribution. Planetangis longicaudata is found in Upper (Liberia, Guinea, Ivory Coast) and Lower Guinea (Nigeria, Cameroon, and Gabon) in West and Central tropical Africa, at 10-650 m. Figure 7.

Habitat and ecology. This species is a large and medium-sized branch, heliophilous epiphyte in lowland evergreen and semi-deciduous rainforest, where it is found growing on tall trees (Adam, 1981; Pérez-Vera 2003). In Ivory Coast, Entandrophragma utile (Dawe \& Sprague) Sprague is reported as a typical phorophyte (Pérez-Vera, 2003).

IUCN Red List category. Planetangis longicaudata is given an IUCN Red List status of Near Threatened [NT]. The EOO of this species is estimated to be $821,624 \mathrm{~km}^{2}$, which far exceeds the $20,000 \mathrm{~km}^{2}$ upper limit for Vulnerable status under criterion B1. Its area of occupancy is estimated to be $48 \mathrm{~km}^{2}$, which falls within the limits for Endangered status under criterion B2. The species is known from 12 subpopulations in the six countries mentioned above. Planetangis longicaudata grows on tall trees in lowland evergreen and semideciduous rainforest between 10 and $650 \mathrm{~m}$ elevation. The species has been collected inside the Cross River National Park, a protected area that has unfortunately been considerably affected by human activities, including logging, slash and burn farming, and poaching (Adetola \& Adetoro, 2014). In Haut-Sassandra, severe encroachment of cocoa into forested areas (see Barima et al., 2016), not far from one of the collecting locations of $P$. longicaudata, has probably taken a toll on the demographics of this subpopulation. In some 
unprotected areas where the species occurs, its habitat is also threatened because of human activities such as shifting agriculture and selective logging. These pressures are gradually leading to the degradation of the quality of its habitat. The main threat to the species is certainly small-scale agriculture, and the 12 subpopulations represent 11 different locations (sensu IUCN, 2019), more than the upper limit for Vulnerable status under subcriterion "a" of criterion B2. Because the conditions for applying at least two subcriteria under criterion B1 or B2 are not met, the species cannot be regarded as threatened even though its AOO falls below the threshold for criterion B2. However, considering the ongoing loss of its habitat within and outside protected areas, the species could become threatened in the near future, a situation that justifies a preliminary risk of extinction assessment of Near Threatended (NT).

Notes. Duplicates of some gatherings from Ivory Coast have been deposited at ABI (Pérez-Vera 533), GDA (Pérez-Vera 146), and UCJ (Pérez-Vera 146) (see Pérez-Vera, 2003), but we were unable to examine these specimens.

Additional specimens examined. LIBERIA. Nimba: Ganta, Teayi, à $60 \mathrm{~km}$ au Sud du Nimba, $426 \mathrm{~m}, 11$ Nov. 1975, Adam 30203 (P). GUINEA. Nzérékoré: Lola, $07^{\circ} 40^{\prime} 02^{\prime \prime} \mathrm{N} 008^{\circ} 19^{\prime} 26^{\prime \prime} \mathrm{W}, 498 \mathrm{~m}, 16$ Jan. 2013, Nimba shade house series 1368 (WAG); ibid. loc., Nimba shade house series 1438 (BRLU); ibid. loc., 3 July 2013, Nimba shade house series 1439 (MO). IVORY COAST. Montagnes: Guézon, route de Guessabo à Duékoué, 1 Nov. 1973, Pérez-Vera 533 (P). BasSassandra: Forêt d'Ouréyo, July 1971, cult. in Daloa, Nov. 1972 (fl.), Pérez-Vera 146 (K). Abidjan: Abidjan, 28 Nov. 1975, de Koning 6213 (WAG); Adiopodoumé, 17 km W of Abidjan, Garden of Centre Néerlandais, N5 ${ }^{\circ} 19^{\prime} 59^{\prime \prime}$ W $4^{\circ} 7^{\prime} 59^{\prime \prime}, 26$ Nov. 1978, Dekker 330 (WAG). NIGERIA. Cross River: C.R.N. Reserve [Cross River Nature Reserve], Nov. 1959, 21 Dec. 1961 (fl.), Cooper 79 (K). S. loc.: cult. in Ibadan, 16 Nov. 1950, FHI 42078 (K, K000615019). CAMEROON. Southwest: KupeManengouba, Mongo-Mdor, N5 ${ }^{\circ} 13^{\prime} 46^{\prime \prime}$, E9 $31^{\prime} 16^{\prime \prime}, 590 \mathrm{~m}, 7$ Dec. 2002, P. Simo \& Zapfack SIP 124 (BRLU, YA); Meme Division, $10 \mathrm{~km} \mathrm{~W}$ of Banga, near Mukete Plantation, N4 ${ }^{\circ} 5^{\prime}$ E9 $23^{\circ}, 50$ m, 30 Oct. 1985, Thomas 4907 (FHI, K, MO, P, WAG, YA). GABON. Woleu-Ntem: région près du Cameroun, Odingoto, 200-300 m, 1 Oct. 1997, Biteau \& Stévart 31 (BRLU); ibid. loc.?, fl., 1 Nov. 2016, Gabon shade house series 507 (BRLU). Moyen-Ogooué: Région de Bifoun, fl., 1 Nov. 2016, Gabon shade house series 666, 668, 815, 883, and 897 (BRLU).

\section{Literature Cited}

Adam, J.-G. 1981. Flore descriptive des Monts Nimba (Côte d'Ivoire, Guinée, Libéria), 5e partie. Editions du CNRS, Paris.

Adetola, B. O. \& A. O. Adetoro. 2014. Threats to biodiversity conservation in Cross River National Park, Nigeria. Int. J. Conserv. Sci. 5: 547-552.

Albuquerque, S., R. K. Brummitt \& E. Figueiredo. 2009. Typification of names based on the Angolan collections of Friedrich Welwitsch. Taxon 58: 641-646.
Andriananjamanantsoa, H. N., S. Engberg, E. E. Louis, Jr. \& L. Brouillet. 2016. Diversification of Angraecum (Orchidaceae, Vandeae) in Madagascar: Revised phylogeny reveals species accumulation through time rather than rapid radiation. PLoS One 11: E0163194.

Arends, J. C. \& F. M. van der Laan. 1986. Cytotaxonomy of the Vandeae. Lindleyana 1: 33-41.

Barima, Y. S. S., A. T. M. Kouakou, I. Bamba, Y. C. Sangne, M. Godron, J. Andrieu \& J. Bogaert. 2016. Cocoa crops are destroying the forest reserves of the classified forest of HautSassandra (Ivory Coast). Global Ecol. Conserv. 8: 85-98.

Beentje, H. 2016. The Kew Plant Glossary, an Illustrated Dictionary of Plant Terms, ed. 2. Royal Botanic Gardens, Kew, Richmond.

Blattner, F. R. 1999. Direct amplification of the entire ITS region from poorly preserved plant material using recombinant PCR. Biotechniques 27: 1180-1186.

Blier, S. P. 1996. African Vodun: Art, Psychology, and Power. University of Chicago Press, Chicago.

Brunken, U., M. Schmidt, S. Dressler, T. Janssen, A. Thiombiano \& G. Zizka. 2008. West African Plants-A Photo Guide. Forschungsinstitut Senckenberg, Frankfurt/Main. $<$ www.westafricanplants.senckenberg.deroot/index.php $>$, accessed 23 November 2018.

Carlsward, B. S. 2014. Subtribe Angraecinae: Phylogenetics. Pp. 338-340 in A. M. Pridgeon, P. J. Cribb, M. W. Chase \& F. N. Rasmussen (editors), Genera Orchidacearum, Vol. 6, Epidendroideae, Part 3. Oxford University Press, Oxford.

Carlsward, B. S., W. M. Whitten \& N. H. Williams. 2003. Molecular phylogenetics of Neotropical leafless Angraecinae (Orchidaceae): Reevaluation of generic concepts. Int. J. Pl. Sci. 164: 43-51.

Carlsward, B. S., W. M. Whitten, N. H. Williams \& B. Bytebier. 2006. Molecular phylogenetics of Vandeae (Orchidaceae) and the evolution of leaflessness. Amer. J. Bot. 93: 770-786.

Chase, M. W., K. M. Cameron, J. V. Freudenstein, A. M. Pridgeon, G. Salazar, C. van den Berg \& A. Schuiteman. 2015. An updated classification of Orchidaceae. Bot. J. Linn. Soc. 177: 151-174.

Cribb, P. J. 1989. Orchidaceae (part 3). Pp. 413-652 in R. M. Polhill (editor), Flora of Tropical East Africa. A. A. Balkema, Rotterdam.

Cribb, P. J. 2014a. Rangaeris. Pp. 427-429 in A. M. Pridgeon, P. J. Cribb, M. W. Chase \& F. N. Rasmussen (editors), Genera Orchidacearum, Vol. 6, Epidendroideae, Part 3. Oxford University Press, Oxford.

Cribb, P. J. 2014b. Podangis. Pp. 424-427 in A. M. Pridgeon, P. J. Cribb, M. W. Chase \& F. N. Rasmussen (editors), Genera Orchidacearum, Vol. 6, Epidendroideae, Part 3. Oxford University Press, Oxford.

Cribb, P. J. \& B. S. Carlsward. 2012. New combinations in Aerangis, Diaphananthe and Podangis (Orchidaceae, subtribe Angraecinae). Phytotaxa 71: 42-47.

Cuénoud, P., V. Savolainen, L. W. Chatrou, M. Powell, R. J. Grayer \& M. W. Chase. 2002. Molecular phylogenetics of Caryophyllales based on nuclear 18S rDNA and plastid $r b c L$, $a t p B$, and matK DNA sequences. Amer. J. Bot. 89: 132-144.

Dauby, G., T. Stévart, V. Droissart, A. Cosiaux, V. Deblauwe, M. Simo-Droissart, M. S. M. Sosef, et al. 2017. ConR: An R package to assist large-scale multispecies preliminary conservation assessments using distribution data. Ecol. Evol. 7: 11292-11303.

Deblauwe, V., V. Droissart, R. Bose, B. Sonké, A. BlachOvergaard, J. C. Svenning, J. J. Wieringa, et al. 2016. Remotely sensed temperature and precipitation data improve species distribution modelling in the tropics. Global Ecol. Biogeogr. 25: 443-454. 
Descourvières, P., J. N. M. Farminhão, V. Droissart, J.-Y. Dubuisson, M. Simo-Droissart \& T. Stévart. 2018. A new genus of angraecoid orchids (Orchidaceae: Angraecinae) with highly distinctive pollinaria morphology, including three new species from tropical West and Central Africa. Phytotaxa 373: 99-120.

D’haijère, T., P. Mardulyn, L. Dong, G. M. Plunkett, M. SimoDroissart, V. Droissart \& T. Stévart. 2019. Molecular phylogeny and taxonomic synopsis of the angraecoid genus Ypsilopus Summerh. (Orchidaceae, Vandeae). Taxon 68: 455-470.

Doyle, J. J. \& J. L. Doyle. 1987. A rapid DNA isolation procedure for small quantities of fresh leaf tissue. Phytochem. Bull. 19: 11-15.

Droissart, V., B. Sonké, M. Simo \& T. Stévart. 2009. New orchid records from Atlantic central Africa. Edinb. J. Bot. 66: 115-132.

Droissart, V., M. Simo, B. Sonké, D. Geerinck \& T. Stévart. 2018. Orchidaceae of Central Africa. <http://www.orchidafrica.net/>, accessed 22 October 2018.

Drummond, A. J., M. A. Suchard, D. Xie \& A. Rambaut. 2012. Bayesian phylogenetics with BEAUti and the BEAST 1.7. Molec. Biol. Evol. 29: 1969-1973.

Edgar, R. C. 2004. MUSCLE: Multiple sequence alignment with high accuracy and high throughput. Nucl. Acids Res. 32: 1792-1797.

Erixon, P., B. Svennblad, T. Britton \& B. Oxelman. 2003. Reliability of Bayesian posterior probabilities and bootstrap frequencies in phylogenetics. Syst. Biol. 52: 665-673.

Farminhão, J. N. M., P. Meerts, P. Descourvières, V. Droissart, M. Simo-Droissart \& T. Stévart. 2018. A revised concept of Rhipidoglossum (Angraecinae, Orchidaceae). Phytotaxa 349: 247-256.

Figueiredo, E. \& G. F. Smith. 2008. Plants of Angola/Plantas de Angola. Strelitzia 22. South African National Biodiversity Institute, Pretoria.

Freudenstein, J. V. \& M. W. Chase. 2015. Phylogenetic relationships in Epidendroideae (Orchidaceae), one of the great flowering plant radiations: Progressive specialization and diversification. Ann. Bot. 115: 665-681.

Govaerts, R., P. Bernet, K. Kratochvil, G. Gerlach, G. Carr, P. Alrich, A. M. Pridgeon, et al. 2019. World Checklist of Orchidaceae. The Board of Trustees of the Royal Botanic Gardens, Kew, <https://www.kew.org/wcsp/>, accessed 18 June 2019.

Huelsenbeck, J. P. \& F. Ronquist. 2001. MRBAYES: Bayesian inference of phylogenetic trees. Bioinformatics 17: 754-755.

IUCN. 2012. IUCN Red List Categories and Criteria, version 3.1, 2nd ed. IUCN Red List Unit, Cambridge. <http:// cmsdocs.s3.amazonaws.com/keydocuments/Categories_and_ Criteria_en_web\%2Bcover\%2Bbckcover.pdf $>$, accessed 23 November 2018.

IUCN. 2019. Guidelines for using the IUCN Red List categories and criteria, version 14. Prepared by the Standards and Petitions Subcommittee of the IUCN Species Survival Commission. <http:// cmsdocs.s3.amazonaws.com/RedListGuidelines.pdf $>$, accessed 6 April 2020.

Johnson, L. A. \& D. E. Soltis. 1994. matK DNA sequences and phylogenetic reconstruction in Saxifragaceae s. str. Syst. Bot. 1: 143-156.

Jones, K. 1967. The chromosomes of orchids: II. Vandeae Lindl. Kew Bull. 21: 151-156.

JSTOR. 2000-2018. Global plants. <https://doi.org/10.2307/ 4108552>, accessed 24 November 2018.

Kränzlin, F. 1894. Orchidaceae africanae. Bot. Jahrb. Syst. 19: 244-255.

Kränzlin, F. 1912. Orchidaceae africanae XI. Bot. Jahrb. Syst. 48: 385-401.
Kress, W. J., L. M. Prince \& K. J. Williams. 2002. The phylogeny and a new classification of the gingers (Zingiberaceae): Evidence from molecular data. Amer. J. Bot. 89: 1682-1696.

Lanfear, R., P. B. Frandsen, A. M. Wright, T. Senfeld \& B. Calcott. 2016. PartitionFinder 2: New methods for selecting partitioned models of evolution for molecular and morphological phylogenetic analyses. Molec. Biol. Evol. 34: 772-773. doi:10.1093/molbev/msw260.

Lee, C. \& J. Wen. 2004. Phylogeny of Panax using chloroplast trnC$t r n \mathrm{D}$ intergenic region and the utility of $t r n \mathrm{C}-t r n \mathrm{D}$ in interspecific studies of plants. Molec. Phylogen. Evol. 31(3): 894-903.

Martins, D. J. \& S. D. Johnson. 2007. Hawkmoth pollination of aerangoid orchids in Kenya, with special reference to nectar sugar concentration gradients in the floral spurs. Amer. J. Bot. 94: 650-659.

Martos, F., T. Le Péchon, S. D. Johnson \& B. Bytebier. 2017. A reassessment of Angraecopsis, Mystacidium and Sphyrarhynchus (Orchidaceae: Vandeae) based on molecular and morphological evidence. Bot. J. Linn. Soc. 186: 1-17.

Micheneau, C., B. S. Carlsward, M. F. Fay, B. Bytebier, T. Pailler \& M. W. Chase. 2008. Phylogenetics and biogeography of Mascarene angraecoid orchids (Vandeae, Orchidaceae). Molec. Phylogen. Evol. 46: 908-922.

Miller, M. A., W. Pfeiffer \& T. Schwartz. 2010. Creating the CIPRES Science Gateway for inference of large phylogenetic trees. Pp. 45-52 in Proceedings of the Gateway Computing Environments Workshop (GCE), New Orleans, Louisiana, 14 Nov 2010, IEEE, Piscataway.

Molvray, M., P. J. Kores \& M. W. Chase. 2000. Polyphyly of mycoheterotrophic orchids and functional influences on floral and molecular characters. Pp. 441-448 in K. L. Wilson, \& D. A. Morrison (editors), Monocots: Systematics and Evolution. CSIRO, Collingwood.

Natural History Museum's Library and Archives. 2019. Welwitsch, Friedrich Martin Josef. Collection of manuscripts and correspondence largely relating to the flora of Angola, including diaries dated 1839, 1851, 1854 and 1859-1861 (MSS WEL). Manuscript at the Natural History Museum (Botany), London. Scan accessed 22 March 2019.

Neubig, K. M., W. M. Whitten, B. S. Carlsward, M. A. Blanco, L. Endara, N. H. Williams \& M. Moore. 2009. Phylogenetic utility of $y c f 1$ in orchids: A plastid gene more variable than matK. Pl. Syst. Evol. 277: 75-84.

Oxelman, B., M. Lidén \& D. Berglund. 1997. Chloroplast rps 16 intron phylogeny of the tribe Sileneae (Caryophyllaceae). Pl. Syst. Evol. 206: 393-410.

Pérez-Vera, F. 2003. Les Orchidées de Côte d'Ivoire. Collection Parthénope, éditions Biotope. Mèze, France.

Pessoa, E. M., J. Viruel, M. Alves, D. Bogarín, W. M. Whitten \& M. W. Chase. 2018. Evolutionary history and systematics of Campylocentrum (Orchidaceae: Vandeae: Angraecinae): A phylogenetic and biogeographical approach. Bot. J. Linn. Soc. 186: 158-178.

R Core Team. 2019. R: A language and environment for statistical computing. R Foundation for Statistical Computing, Vienna. <https://www.R-project.org/>, accessed 10 February 2019.

Rambaut, A., A. J. Drummond, D. Xie, G. Baele \& M. A. Suchard. 2018. Posterior summarisation in Bayesian phylogenetics using Tracer 1.7. Syst. Biol. 67: 901-904.

Rice, R. 2005. A Preliminary Checklist and Survey of the Subtribe Aerangidinae (Orchidaceae). Oasis The Journal Publishing Department, Dora Creek, Australia.

Rice, R. 2006. Notes on the subtribe Aerangidinae (Orchidaceae). Oasis 3: 12-15. 
Ronquist, F., M. Teslenko, P. Van der Mark, D. L. Ayres, A. Darling, S. Höhna, B. Larget, et al. 2012. MrBayes 3.2: Efficient Bayesian phylogenetic inference and model choice across a large model space. Syst. Biol. 61: 539-542.

Rudall, P. J., R. M. Bateman, M. F. Fay \& A. Eastman. 2002. Floral anatomy and systematics of Alliaceae with particular reference to Gilliesia, a presumed insect mimic with strongly zygomorphic flowers. Amer. J. Bot. 89: 1867-1883.

Schlechter, R. 1918. Versuch einer natürlichen Neuordnung der afrikanischen angraekoiden Orchidaceen. Beih. Bot. Centralbl. 36: 62-181.

Simo-Droissart, M., G. M. Plunkett, V. Droissart, M. B. Edwards, J. N. M. Farminhão, V. Ječmenica, T. D'haijère, et al. 2018a. New phylogenetic insights toward developing a natural generic classification of African angraecoid orchids (Vandeae, Orchidaceae). Molec. Phylogen. Evol. 126: 241-249.

Simo-Droissart, M., B. Sonké, V. Droissart \& T. Stévart. 2018b. Afropectinariella (Vandeae, Orchidaceae), a new genus of the Angraecum alliance. PhytoKeys 96: 79-86.

Simo-Droissart, M., T. Stévart, B. Sonké, S. Mayogo, N. Kamdem \& V. Droissart. 2018c. New taxonomic and conservation status of Ossiculum (Vandeae, Orchidaceae), a highly threatened and narrow-endemic angraecoid orchid from Central Africa. PhytoKeys 98: 85-97.

Stamatakis, A. 2014. RAxML Version 8: A tool for phylogenetic analysis and post-analysis of large phylogenies. Bioinformatics 30: 1312-1313.

Stévart, T. \& F. Oliveira. 2000. Guide des Orchidées de São Tomé et Príncipe: Guia dos Orchídeas de São Tomé e Príncipe. ECOFAC, São Tomé.

Stévart, T., E. Akouangou, L. Andriamahefarivo, F. Andriatsiferana, L. Azandi, B. Bakita, J.-P. Biteau, et al. 2020. The Missouri Botanical Garden, Africa \& Madagascar. Pp. 26-43 in J. Hermans, C. Hermans, J. Linsky \& C. W. Li (editors), World Orchid Collections 2020. Taiwan Orchid Growers Association (TOGA), Taiwan.

Summerhayes, V. S. 1936a. African Orchids: VIII. Bull. Misc. Inform. Kew 1936: 221-233.

Summerhayes, V. S. 1936b. Orchidaceae. Pp. 400-463 in J. Hutchinson \& J. M. Daziel (editors), Flora of West Tropical Africa, Vol. 2. Crown Agents for the Colonies, London.

Systematics Association Committee for Descriptive Biological Terminology. 1962a. II. Terminology of simple symmetrical plane shapes (chart 1). Taxon 11: 145-156.

Systematics Association Committee for Descriptive Biological Terminology. 1962b. IIa. Terminology of simple symmetrical plane shapes (chart 1a). Taxon 11: 245-247.

Szlachetko, D. L. \& T. S. Olszewski. 2001. Orchidacées 3. Pp. 666-948 in G. Achoundong \& P. Morat (editors), Flore du Cameroun, Vol. 36. Ministère de la Recherche Scientifique et Technique, Yaoundé, Cameroon.

Taberlet, P., L. Gielly, G. Pautou \& J. Bouvet. 1991. Universal primers for amplification of 3 noncoding regions of chloroplast DNA. Pl. Molec. Biol. 17: 1105-1109.

Thiers, B. [continuously updated]. Index Herbariorum: A global directory of public herbaria and associated staff. New York Botanical Garden's Virtual Herbarium. $<$ http://sweetgum.nybg.org/science/ih/>, accessed 23 November 2018.

Turland, N. J., J. H. Wiersema, F. R. Barrie, W. Greuter, D. L. Hawksworth, P. S. Herendeen, S. Knapp, et al, (editors). 2018. International Code of Nomenclature for algae, fungi, and plants (Shenzhen Code). Regnum Veg. 159.

World Orchid Iconography. 2015-2018. World orchid iconography. Swiss Orchid Foundation at the Herbarium Jany Renz, Botanical Institute, University of Basel. <https:// orchid.unibas.ch/index.php/en/database-search/ advanced-search $>$, accessed 24 November 2018.

Appendix 1. List of the 39 specimens utilized in the molecular analyses including outgroups. Sampled species are listed alphabetically. The herbarium where the voucher specimen is currently housed is cited in parentheses. GenBank accession numbers are included for each of the six genic regions used in the current study (ITS, trnL-trnF intergenic spacer, matK, rps16, trnC-pet $N$ intergenic spacer, and $y c f 1)$. The asterisk (*) indicates those sequences produced during this study. The en dash (-) denotes that no data are available for that region.

Aerangis gracillima (Kraenzl.) J. C. Arends \& J. Stewart, Yaoundé shade house series 1404 (BRLU), MH237060, MH237436, MK685530, *, *, *; Aziza trilobata (Summerh.) Farminhão \& D'haijère, Gabon, D'haijère et al. 2 (BRLU), *,-, *, -, -, *; Aziza trilobata (Summerh.) Farminhão \& D'haijère, Gabon, Farminhão et al. 11 (BRLU), *, -, *, -, -, *; Aziza trilobata (Summerh.) Farminhão \& D'haijère, São Tomé and Príncipe, D'haijère et al. 137 (BRLU), *,-, *,-,-,-; Cyrtorchis arcuata (Lindl.) Schltr. subsp. arcuata, Cameroon, Yaoundé shade house series 2761 (BRLU), *, -, -, *, *, *; Cyrtorchis arcuata (Lindl.) Schltr. subsp. whytei Summerh., Cameroon, Yaoundé shade house series 2883 (BRLU), *, -, -, *, *, *; Cyrtorchis ringens (Rchb. f.) Summerh., Cameroon, Yaoundé shade house series 1306 (BRLU), MH237053, MH237428, MK685421, *, *, *; Listrostachys pertusa (Lindl.) Rchb. f., Cameroon, unvouchered, MH237083, MH237463, MK685556, *, *, *; Mystacidium capense (L. f.) Schltr., ex hort. Countryside Orchids, Whitten 1787 (FLAS), DQ091571, DQ091485, DQ091360, *, *, *; Nephrangis filiformis (Kraenzl.) Summerh., Cameroon, Yaoundé shade house series 2916 (BRLU), MH237085, MH237466, MK685558, *, *, *; Planetangis longicaudata (Rolfe) Stévart \& Farminhão, Gabon, Gabon shade house series 666 (BRLU), *, -, *, -, -, -; Planetangis longicaudata (Rolfe) Stévart \& Farminhão, Gabon, Gabon shade house series 668 (BRLU), MH237161, MH237546, -, -, *, *; Planetangis longicaudata (Rolfe) Stévart \& Farminhão, Guinea, Nimba shade house series 1584 (BRLU), *,-,-, -, -, -; Plectrelminthus caudatus (Lindl.) Summerh., Cameroon, Yaoundé shade house series 2803 (BRLU), MH237090, MH237470, MK685563, MK721992, -, MK722023; Podangis dactyloceras (Rchb. f.) Schltr., Cameroon, Yaoundé shade house series 2652 (BRLU), MH237089, MH237469, MH748944, *, *, *; Podangis dactyloceras (Rchb. f.) Schltr., cult. K, Kew 4999 (K), DQ091628, DQ091510, DQ091385, *, *, *; Podangis dactyloceras (Rchb. f.) Schltr., unknown provenance, Z. J. Liu 7179 (NOCC), KJ021018, KJ021010, KJ021022, -, -, -; Podangis rhipsalisocia (Rchb. f.) P. J. Cribb \& Carlsward, Cameroon, Yaoundé shade house series 2011 (BRLU), MH237092, MH237473, MK685566, *, *, *; Podangis rhipsalisocia (Rchb. f.) P. J. Cribb \& Carlsward, Cameroon, Yaoundé shade house series 2644 (BRLU), -, MH237472, MK685565, *, *, *; Rangaeris muscicola (Rchb. f.) Summerh., cult. SEL, Carlsward 169 (SEL), DQ091630, DQ091513, DQ091387, *, *, EU490774; Rangaeris muscicola (Rchb. f.) Summerh., Countryside Orchids, Carlsward 400 (FLAS), DQ091631, -, -, -, -, -; Rangaeris muscicola (Rchb. f.) Summerh., Guinea, Nimba shade house series 1860 (BRLU), *, -, -, -, -, -; Rangaeris muscicola (Rchb. f.) Summerh., Cameroon, Yaoundé shade house series 3073 (BRLU), *, -, -, -, -, *; Rangaeris muscicola (Rchb. f.) Summerh., Cameroon, Yaoundé shade house series 7298 (BRLU), *, -, -, -, -, *; Solenangis scandens (Schltr.) Schltr, Cameroon, cult. Yaoundé shadehouse Y 3308 YK, -, MK722044, MK722038, MK722019, MK721987, MK697510; Summerhayesia laurentii 
(De Wild.) P. J. Cribb, Gabon, in cult. Jardi-Gab BTO 220, *, *, -, *, -, *; Tridactyle anthomaniaca (Rchb. f.) Summerh., Cameroon, cult. Yaoundé shade house Y3679 RH (BRLU), MH236990, MH237359, MK685461, MK721977, MK697519, MK722009; Tridactyle bicaudata (Lindl.) Schltr., Rwanda, Farminhão \& Dumbo 221 (BRLU), *, *, *, *, *, -; Tridactyle bicaudata (Lindl.) Schltr., Rwanda, Farminhão \& Dumbo 296 (BRLU), *, *, *, *, *, -; Tridactyle gabonensis (P. J. Cribb \& Laan) R. Rice, Gabon, cult. Ombrière de Sibang 200 (BRLU), MH237166, MH237551, MK685633, *, *, *; Tridactyle latifolia Summerh., Príncipe, Primo \& Stévart 94 (BRLU), MH237024, MH237398, MK685491, MK721988, MK697509, MK722020; Tridactyle laurentii (De Wild.) Schltr., Gabon, unvouchered, MH236982, MH237351, MK685453, MK721996, MK697523, MK722027; Tridactyle tridactylites (Rolfe) Schltr.,
Cameroon, Yaoundé shade house series 1993 (BRLU), MH236989, MH237358, MK685460, MK721975, MK697516, MK722007; Ypsilopus amaniensis (Kraenzl.) D'haijère \& Stévart, Kenya, Bytebier \& Kirika 26 (EA), DQ091634, DQ091512, DQ091386, MK721981, MK697524, MK722013; Ypsilopus erectus (P. J. Cribb) P. J. Cribb \& J. Stewart, Kenya, Grieve 1244 (EA), MK714122, MK722042, MK722036, MK721991, MK697515, MK722022; Ypsilopus longifolius (Kraenzl.) Summerh., cult. NYBG, MO4274452 (NY), MH237190, MH237578, -, MK722000, MK697532, MK722032; Ypsilopus schliebenii (Mansf.) D'haijère \& Stévart, cult. BR 20090389-40, MH236965, MH237334, MK685438, -, -, -; Ypsilopus viridiflorus P. J. Cribb \& J. Stewart, Tanzania, Bytebier 402 (EA), DQ091633, -, DQ091395, MK721971, -, MK722003. 